\title{
The Anaerobic Fungi: Challenges and Opportunities for Industrial Lignocellulosic Biofuel Production
}

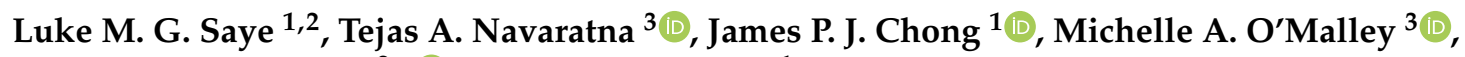 \\ Michael K. Theodorou ${ }^{2, *}$ (D) and Matthew Reilly ${ }^{1, *}$ \\ 1 Department of Biology, University of York, York YO10 5DD, UK; lmgs502@york.ac.uk (L.M.G.S.); \\ james.chong@york.ac.uk (J.P.J.C.) \\ 2 Department of Agriculture and the Environment, Harper Adams University, \\ Newport TF10 8NB, UK \\ 3 Department of Chemical Engineering, University of California, Santa Barbara, CA 93106, USA; \\ tejasn@ucsb.edu (T.A.N.); momalley@ucsb.edu (M.A.O.) \\ * Correspondence: mtheodorou@harper-adams.ac.uk (M.K.T.); matthew.reilly@york.ac.uk (M.R.)
}

\section{check for} updates

Citation: Saye, L.M.G.; Navaratna T.A.; Chong, J.P.J.; O'Malley, M.A.; Theodorou, M.K.; Reilly, M. The Anaerobic Fungi: Challenges and Opportunities for Industrial Lignocellulosic Biofuel Production. Microorganisms 2021, 9, 694. https://doi.org/10.3390/ microorganisms 9040694

Academic Editor: Sabine Marie Podmirseg

Received: 17 February 2021

Accepted: 18 March 2021

Published: 27 March 2021

Publisher's Note: MDPI stays neutral with regard to jurisdictional claims in published maps and institutional affiliations.

Copyright: (c) 2021 by the authors. Licensee MDPI, Basel, Switzerland. This article is an open access article distributed under the terms and conditions of the Creative Commons Attribution (CC BY) license (https:/ / creativecommons.org/licenses/by/ $4.0 /)$.

\begin{abstract}
Lignocellulose is a promising feedstock for biofuel production as a renewable, carbohydraterich and globally abundant source of biomass. However, challenges faced include environmental and/or financial costs associated with typical lignocellulose pretreatments needed to overcome the natural recalcitrance of the material before conversion to biofuel. Anaerobic fungi are a group of underexplored microorganisms belonging to the early diverging phylum Neocallimastigomycota and are native to the intricately evolved digestive system of mammalian herbivores. Anaerobic fungi have promising potential for application in biofuel production processes due to the combination of their highly effective ability to hydrolyse lignocellulose and capability to convert this substrate to $\mathrm{H}_{2}$ and ethanol. Furthermore, they can produce volatile fatty acid precursors for subsequent biological conversion to $\mathrm{H}_{2}$ or $\mathrm{CH}_{4}$ by other microorganisms. The complex biological characteristics of their natural habitat are described, and these features are contextualised towards the development of suitable industrial systems for in vitro growth. Moreover, progress towards achieving that goal is reviewed in terms of process and genetic engineering. In addition, emerging opportunities are presented for the use of anaerobic fungi for lignocellulose pretreatment; dark fermentation; bioethanol production; and the potential for integration with methanogenesis, microbial electrolysis cells and photofermentation.
\end{abstract}

Keywords: anaerobic fungi; dark fermentation; lignocellulose; bioethanol; biohydrogen; biofuel; pretreatment; photofermentation; microbial electrolysis cell; methanogenesis

\section{Introduction}

New approaches are needed to reduce the use of fossil fuels and harness the global abundance of lignocellulosic biomass for biofuel production. Lignocellulosic feedstocks can be converted to biofuels but they require costly and environmentally damaging pretreatments in order to overcome their inherent recalcitrance to degradation [1,2]. Anaerobic fungi, belonging to the phylum Neocallimastigomycota, may provide a green solution because they have an unprecedented ability to deconstruct crude lignocellulose [3,4] and are able to convert polymeric plant cell wall components to $\mathrm{H}_{2}$ [5] and ethanol [6]. This group of organisms can also produce volatile fatty acids (e.g., acetic and formic acid [5]) which are suitable substrates for additional downstream biofuel production.

Anaerobic fungi are commonly found in the digestive tracts of large mammalian herbivores, including many important livestock and companion animal species such as cattle, sheep, goats and horses. Prior to their correct affiliation [7-9] zoospores of anaerobic fungi were mistakenly classified as protozoa. Callimastix frontalis and C. equi zoospores, found in horse intestines, were both described as polyflagellated protozoans $[10,11]$ and placed 
in the same genus as C. cyclopsis, a parasite of freshwater copepods [12,13]. Monoflagellated zoospores, found in ruminants, were also recognised as protozoa and assigned to the protozoan genera Piromonas and Sphaeromonas $[10,14]$. The discovery that $C$. cyclopsis was a fungal pathogen (belonging to the Blastocladiomycota) led to the transfer of C. equi and $C$. frontalis to a new protozoan genus, Neocallimastix, with $N$. frontalis as the type species [15]. Following the seminal work of Orpin [7-9] and their correct assignment as fungi, based upon the ultrastructure of their motile zoospores, anaerobic fungi were initially placed in the order Spizellomycetales but later transferred to their own order, the Neocallimastigales, in the phylum Chytridiomycota [16]. Genetic analysis identifies that Neocallimastigomycota is a distinct basal clade of the chytrids [17]. The order, which now houses 18 different genera of anaerobic fungi, was therefore raised to the level of a phylum, the Neocallimastigomycota, in 2007 [17,18].

The Neocallimastigomycota, Blastocladiomycota and Chytridiomycota are all closely related. Although fungi in the latter two phyla are aerobic and mostly found in fresh water and wet soils (some are parasitic), fungi in all three phyla display similarities in their adaptations to an aquatic lifestyle. These adaptations include a dependence on zoospore release in the aquatic environment for dispersal (via asexual reproduction) and similarities in vegetative thallus morphology, including the ability to grow on and within surfaces and substrates. Additionally, a dormant phase has been observed in all three phyla, where the fungi can survive relatively adverse conditions, sometimes for many months [19-21]. However, the Neocallimastigomycota differ from the blastoclades and chytrids in their anaerobic lifestyle and flagella apparatus. They also possess hydrogenosomes and a complete absence of mitochondria $[19,22,23]$. From an evolutionary perspective, these three phyla are basal fungal clades with species and genera that are the direct decedents of some of the earliest diverging fungal lineages. It has been proposed that that the Neocallimastigomycota diverged from other primitive aquatic fungi during the late Cretaceous period when grasses and grazing mammalian herbivores first appeared [24].

Due to their highly effective ability to convert lignocellulose into biofuels and biofuel precursors, anaerobic fungi are biotechnologically interesting. In this review, the challenges and opportunities associated with exploiting anaerobic fungi for the purpose of industrial biofuel production are discussed. Prior to discussing the challenges and opportunities for their exploitation in the biofuel industry, a review of the niche anaerobic fungi occupy in the mammalian digestive tract is presented, drawing in particular upon the substantial amount of literature involving ruminant livestock. This is necessary in the context of this review, as an in-depth appreciation of their natural niche will assist in developing appropriate methodologies for their exploitation in an industrial context.

\section{The Gastrointestinal Tract of Herbivores}

Ruminant nutrition and rumen function in domesticated livestock are mature and extensively researched scientific disciplines. This is because they are highly influential on productivity in farmed livestock and therefore impact farm profitability. Some of the more salient features of rumen function exemplify the precise nature of the ecological niche occupied by anaerobic fungi in the digestive tract ecosystem. They also provide a natural blueprint of what will be needed for in vitro exploitation of anaerobic fungi in an industrial context.

\subsection{Rumen Function}

There are two types of mammalian herbivores. Ruminant herbivores (cloven hoofed mammals), those in which a proportion of the gastrointestinal tract has been enlarged to produce a large fore-stomach (the rumen and reticulum) in which microbial digestion precedes gastric digestion, and hind-gut fermenting herbivores such as horses and elephants. A common constituent of the diets of these animals is lignocellulose found in monocotyledonous grasses and herbaceous woody plants. In order to deconstruct and utilise these recalcitrant materials, mammalian herbivores rely on a complex microbial 
consortium, resident in the gastrointestinal tract, to produce the variety of enzymes needed to degrade complex lignocellulosic substrates. Plant biomass is effectively converted by the consortium to microbial biomass and fermentation end-products, thereby providing nutrition and energy for the host animal. The evolved mechanism for selective retention of plant biomass in the rumen enables ruminant herbivores to achieve extensive degradation of plant fibre. One consequence of selective retention is that the accumulation of plant biomass in the reticulo-rumen restricts feed intake, which requires this organ to be relatively large (with a volume of 100-150 L in cattle and approximately $10 \mathrm{~L}$ in sheep [25]). Microbial digestion in hind-gut fermenting herbivores occurs mainly in the caecum and large intestines and follows gastric digestion. In comparison to ruminants, where feed particles can be retained in the rumen for 58-65 h (cattle), feed particles pass through the digestive system of hindgut-fermenting mammals relatively quickly (24-48 h, horse), and recalcitrant plant materials are not therefore digested as extensively [26-28].

The ability to consume and digest plant polymers is most advanced in ruminant species. The foregut in these animals consists of four stomachs (Figure 1). The first three (the rumen, reticulum and omasum) are pre-gastric organs formed from modifications of the oesophagus. The fourth, the abomasum, is the site of gastric digestion, equivalent to the single stomach in monogastric mammals. The rumen contains an anoxic environment, homeostatically held at $39^{\circ} \mathrm{C}$ and buffered at a pH of between 6 and 7 . The digesta within are stratified into gas, liquid and solid; with solid particles of different sizes and densities. Feedstuffs do not just enter and exit the rumen. Instead, ingested feedstuffs travel along complicated flow-paths and are subjected to extensive mixing. Grazing ruminants typically swallow a feed bolus of plant material with minimal mastication. The rumen (or first stomach) receives the bolus and copious quantities of bicarbonate buffered saliva (6-16 $\mathrm{L} \mathrm{d}^{-1}$ in sheep and 98-190 $\mathrm{L} \mathrm{d}^{-1}$ in cattle [29]) from the oesophagus. The ingested biomass undergoes partial digestion in the rumen prior to being regurgitated, masticated (chewing the cud) and re-swallowed. Adequate mixing of digesting particles, microbial biomass, saliva and drinking water is assured by the grazing behaviour and synchronised rhythmic muscular contractions of the reticulo-rumen. Mastication, coupled with muscular contractions and the activity of microbial enzymes in the reticulo-rumen, ensures adequate digestion and particle-size reduction. Comminuted particles below a certain size (typically 1.5-2.0 mm in cattle [30,31]), liquids and free-floating microorganisms leave the rumen via the reticuluo-omasal orifice at the distal end of the omasum. The orifice, comprised of a series of "interlaced leaves" acts as a filtration and sieving mechanism, permitting the flow of liquids, free-floating microorganisms and smaller particles out of the rumen while preventing passage of larger, less digested particles. It is also the site where significant amounts of water and fermentation acids are absorbed by the animal. Thereafter, small digesta particles and microbial biomass undergo gastric digestion in the abomasum (true stomach) prior to passing to the hind-gut where further microbial activity can ensue. The retention times for liquids and small particles, including microorganisms, in the rumen are in the range from 10 to $24 \mathrm{~h}$, whereas larger plant particles may remain in the rumen for 48-72 h, allowing more time for extensive microbial digestion of plant fibres [25]. Rumen function enables a large proportion of ingested plant biomass to be converted to microbial cells, gaseous and soluble fermentation end-products. Gaseous end-products (predominantly $\mathrm{CO}_{2}$ and $\mathrm{CH}_{4}$ ) are eructed via the oesophagus and soluble fermentation products enter the blood stream via absorption across the reticulo-rumen wall. Although ruminant and hind-gut fermenting herbivores have similar intestinal microbiomes [32], they digest plant tissues differently. Due to the different physiology of their gastrointestinal tracts, in hind-gut herbivory a greater portion of the nutrient supply to the animal is obtained from the contents rather than the walls of plant cells [33]. For a comprehensive account of the nutritional ecology of ruminants, please refer to Van Soest [34]. 


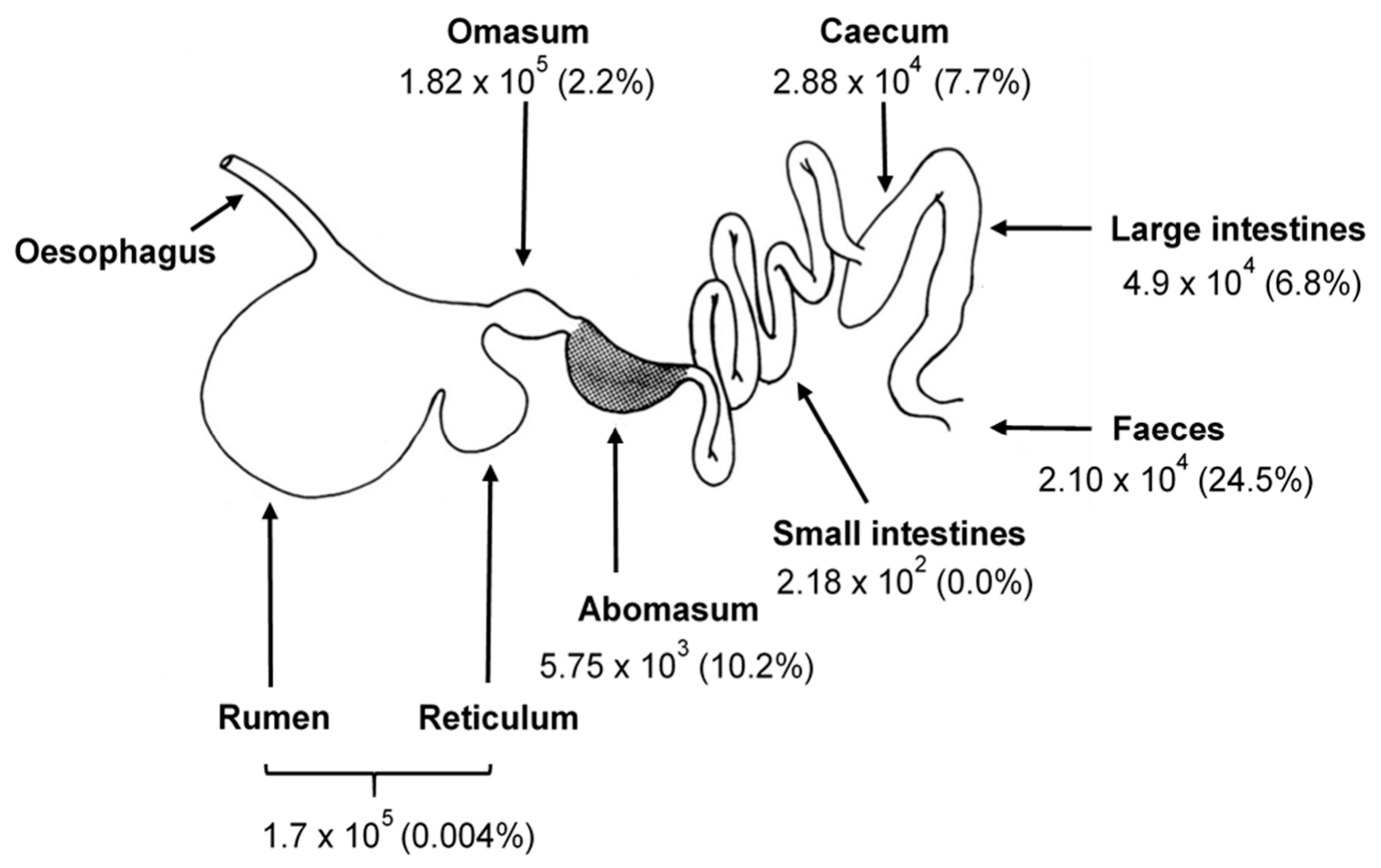

Figure 1. Diagrammatic representation of the ruminant digestive tract. Microbial digestion in the reticulo-rumen precedes gastric digestion which takes place in the abomasum, or true stomach. Values are presented for culturable anaerobic fungal populations (i.e., the number of thallus forming units per gram of dry matter, TFU $\mathrm{g} \cdot \mathrm{DM}^{-1}$ ) in digesta taken from each organ of the digestive tract of grass-silage fed, 8-month-old growing steers. Values in parentheses represent the percentage of the fungal population that survived and were culturable after 7 days of drying digesta or faecal contents at ambient temperature. Data taken from Davies et al. [20].

The brief description presented above serves to demonstrate the exquisite syntrophy that has evolved over millennia to enable ruminants to derive energy and nutrition from the consumption, microbial deconstruction and fermentation of structural plant polysaccharides. In essence, the rumen is an anaerobic fermenting environment that functions to enable retention of larger plant biomass particles while allowing passage of smaller particles, liquids and free-floating microbial cells to the lower gut. It is an open (continuous culture), high dry matter fermentation system in which plant biomass is preferentially retained based on particle size until masticated and digested to be small enough to pass out of the rumen. End-product toxicity in this high-substrate containing environment is mitigated by eructation of fermentation gases via the oesophagus and diffusion of aqueous fermentation end-products across the reticulo-rumen wall. An understanding of the intricacies of the herbivore digestion system is relevant because certain aspects of this natural blueprint will be required to accommodate industrial growth of anaerobic fungi for biofuel production.

\subsection{The Relative Functional Role of Anaerobic Fungi}

The plant fibre-degrading consortia in ruminants consists of anaerobic bacteria, archaea, protozoa and fungi. While each contributing species plays a part in the deconstruction of lignocellulose, due to the complexity of the community and ecosystem, it is challenging to assign and quantify relative roles to individual members of the consortium. It has been postulated that fibrolytic bacteria degrade particles of plant biomass by erosion, whereas rumen fungi degrade by invasion [35]. These two mechanisms of degradation may permit survival of both populations in a highly competitive ecosystem [36]. The concept of erosion versus invasion as a hypothesis for fungal survival is also the origin of the assertion that anaerobic fungi may contribute as primary colonisers of plant biomass [37]. 
This claim is supported by the observation that perennial ryegrass leaf blades in the rumen are colonised by anaerobic fungi within the first few minutes of their contact with rumen fluid [38]. The number of free-swimming fungal zoospores encountered in the rumen is typically within the range of $1 \times 10^{4}-1 \times 10^{5}$ per $\mathrm{mL}$ of rumen fluid [7-9,39]. Given the temporal sequence of events in the fungal life cycle and the fact that many zoospores (10-120 per zoosporangium) are liberated from each vegetative thallus $[40,41]$, it seems unlikely that the overall contribution made by anaerobic fungi to fibre deconstruction in the rumen will be large in comparison to the contribution made by fibrolytic bacteria. From the enumeration studies of Leedle et al. [42], it can be calculated that rumen bacteria typically outnumber fungal zoospores by up to 250,000:1. Acknowledging that many of these bacteria may not be fibrolytic, it might be expected that faster-growing and more numerous fibre-degrading species will survive at the expense of the less competitive anaerobic fungi. However, there is an increasing body of evidence to suggest that despite their lack of numerical abundance, anaerobic fungi make a contribution to the degradation of fibre in the rumen that is not negligible [36,43-45].

\subsection{Life Cycle and Niche of Anaerobic Fungi}

The anaerobic Neocallimastigomycota are aquatic, zoospore-producing fungi with a life history that has evolved over millennia to be uniquely adapted to a specific niche in the digestive tract ecosystem. Their life cycle involves a zoosporic dispersal phase, whereby freshly liberated zoospores are chemotactically attracted, settle and encyst on recently ingested plant biomass. Encysted zoospores germinate to produce a benthic, vegetative stage consisting of a rhizoidal or bulbous thallus which grows on the surface and throughout the substrate. Broadly speaking, anaerobic fungi can be subdivided between two distinct types based on the morphology of their fungal thallus. Monocentric fungi have a determinate life cycle, whereby the fungal thallus produces just one zoosporangium where all of the DNA is retained in the developing zoospores. When mature, the zoosporangium liberates its zoospores and the residual thallus, now devoid of nuclear material, autolyses without further development [40]. This finite growth habit is not unusual among zoosporic fungi. However, it is of consequence in an industrial context because it dictates that both zoospores and thalli are required for continuous biomass production. By contrast, nuclei are present in the bulbous or rhizoidal networks of polycentric fungi. Their life cycle is described as indeterminate because the thallus typically produces many zoosporangia per fungal thallus [46]. The development of a polycentric thallus with a nucleated rhizomycelium is considered as major step in fungal evolution, enabling the capacity for vegetative reproduction by fragmentation. In contrast to monocentric fungi, polycentric fungi have developed the ability to survive without the need for zoospore production. As both the vegetative and reproductive stages do not need to be accommodated, polycentric fungi may be more amenable to growth in industrial-scale bioreactors.

The life cycle in both aerobic and anaerobic zoosporic fungi is completed rapidly, resulting in the release of large numbers of zoospores. From studies conducted in the laboratory, it has been estimated that the duration of the anaerobic fungal life cycle is about 24-32 $\mathrm{h}[40,47]$. However, under appropriate conditions in the animal, zoosporogenesis can take place as early as $8 \mathrm{~h}$ after encystment [48]. Research with ruminants suggests that the life cycle is synchronised to coincide with the feeding regime of the host $[43,48,49]$. Zoospores can respond chemotactically to diffusible components both in vivo in the animal in response to freshly ingested plant fragments [50], and in vitro, in the laboratory in response to soluble sugars and plant derived haemin and phenolic acids [51,52]. Evidence suggests that freshly ingested plant biomass triggers zoospore release from mature zoosporangia $[48,50]$ and that within a matter of minutes, free-swimming zoospores rapidly colonise recently ingested biomass [38]. It is possible that zoosporogenesis is triggered by soluble constituents emanating from freshly ingested feed boli and that newly ingested feed boli are the primary sites of colonisation for fungal zoospores in the rumen. It is also possible that the life cycle of anaerobic fungi in the rumen may be restricted to the 
initial (primary) colonisation of freshly ingested feed boli and completed within a few hours, prior to mastication and re-swallowing of the regurgitated bolus. These points may be important considerations, relevant to bioreactor design because they suggest that the duration of the life cycle in vivo is quicker than that determined in vitro. They also suggest that the duration of the life cycle is not fixed but is influenced by environmental factors, particularly the type and temporal availability of plant biomass constituents.

A third stage in the fungal life cycle, an aero-tolerant survival stage, has been reported to occur when conditions for vegetative growth in the rumen become less favourable [20,21]. Research suggests that these survival structures are thick-walled, aerotolerant, desiccationresistant zoosporangium formed by a proportion of the anaerobic fungi leaving the rumen. They have been quantified in cattle in all organs of the digestive tract and in faeces [20] (Figure 1). They are reported to germinate when conditions become favourable again, either in the hind-gut or after defaecation and re-introduction to a new host animal $[20,21,53]$. These results $[20,21,53]$ and the fact that viable zoospores have never been observed in ruminant faeces (M.K.T. unpublished observations) suggest that stress-tolerant sporangial structures may be important for the transfer of viable fungi between herbivorous hosts.

While anaerobic fungi occupy a niche in the gastrointestinal tract where environmental conditions are relatively constant, by contrast, many aerobic zoosporic fungi occupy ecological niches that are subjected to changing environmental conditions. They have therefore developed various ecological strategies to enable them to survive transiently stressful conditions [54]. Given their common ancestry, it is reasonable to expect that the anaerobic fungi will have evolved mechanisms similar to their aerobic counterparts that enable them to persist in a dormant state outside of their mammalian host. While stress-tolerant, anaerobic fungal-resistant structures have been identified in digesta samples and in faeces, the ability to produce and germinate them in laboratory culture has not yet been achieved. This aspect of their life cycle requires further research as the ability to manipulate viable stress-tolerant structures in vitro could alleviate the need for repeated sub-culturing and therefore simplify inoculation and maintenance of anaerobic fungi in industrial fermentation processes.

\section{Process Engineering and Genetic Engineering}

A combination of process engineering and genetic (molecular) engineering approaches can aid the successful transposition of anaerobic fungi from their natural habitat in herbivores to effective exploitation in industrial biofuel production. The discipline of process engineering will be necessary to synthetically create a suitable habitat and environment in which an unnaturally large population of anaerobic fungi can resiliently prosper as a monoculture or co-culture in the absence of the host animal. The application of process engineering should include attention to design aspects such as the structure of fermentation vessels, solid and liquid amounts and retention times, suitable inoculation and plant biomass feeding regimes (batch or continuous). Genetic engineering provides the opportunity to manipulate anaerobic fungal cells and exploit their genetic potential for the purposes of higher product yields, increased environmental resilience and faster hydrolysis of lignocellulose material. Therefore, this section will discuss the current progress, challenges and future goals relating to achieving and optimising the industrial use of anaerobic fungi via both approaches.

\subsection{Process Engineering}

According to Dal Pont [55], process engineering can be summarised as the understanding and application of the fundamental principles and laws of nature that allow us to transform raw material and energy into products that are useful to society, at an industrial level. As yet, understanding of the anaerobic fungi falls far short of them being able to transform lignocellulosic substrates into biofuel energy products that are useful to society at an industrial scale. Moreover, it is important to underscore the significance of the anaerobic fungal niche in the mammalian digestive tract when considering opportunities 
and challenges for their biotechnological exploitation. On the one hand, an alternation of generations between reproductive motile zoospores and benthic, vegetative fungal thalli represent limitations (certainly for monocentric fungi) that must be accommodated if they are to be grown successfully in industrial processes. On the other hand, much can be learnt and potentially exploited (particularly from an engineering perspective) from a detailed understanding of the way in which the anaerobic fungi thrive and deconstruct lignocellulosic substrates in their natural habitat.

\subsubsection{Anaerobic Fungi in Anaerobic Digestion (AD)}

Anaerobic fungi reside in and are easily isolated in culturable form from the digestive tract of large herbivorous mammals. In these environments, lignocellulosic substrates are abundant and oxygen is absent. Many other anaerobic environments contain an abundance of lignocellulose and might also support anaerobic fungi. For example, anoxic zones in landfill sites, anoxic muds and marshlands and purpose-built anaerobic digesters. Multiple studies have demonstrated that DNA extracted from these sites map unequivocally to the Neocallimastigomycota, suggesting that anaerobic fungi may be present and are not exclusively gut inhabitants [20,21,56-61]. However, the prevalence of large numbers of stress-tolerant survival structures in the faeces of mammalian herbivores means that their nucleic acid motifs will be abundant and widespread in nature. Therefore, it is to be expected that molecular signatures of anaerobic fungi will be found in a broad range of habitats outside of the gastrointestinal tract, wherever faeces are deposited. Detection of fragments of nucleic acid belonging to the anaerobic fungi in these locations should not be taken as evidence of their ability to undergo vegetative growth and reproduction. Where anaerobic fungi have been sought in landfill sites using culture methodologies, they have not been found [62].

In recent research, several studies have investigated the use of anaerobic fungi for bioaugmentation in industrial anaerobic digestion (AD) plants [57,58,63-65]. The rationale for inferring a role for anaerobic fungi in AD implies analogy with the digestive tract ecosystem. In both environments, complex molecules of plant origin are converted into simple organic molecules. The rationale is also cognisant of the fact that anaerobic fungi in their natural habitat form stable, syntrophic co-cultures with methanogenic archaea $[5,66,67]$. If anaerobic fungi could be successfully utilised in an AD plant, they could allow lignocellulose to become a major feedstock, representing an important step-change in the bioremediation process. Genetic motifs of anaerobic fungi have been found in industrial AD plants. In one study, 10 commercial plants in Germany were surveyed for transcriptional activity [57]. Anaerobic fungal 18S DNA was found, but only in plants that received cattle manure and of those, only two were found to contain GH5 endonuclease transcripts, suggesting metabolic activity. Others have also found genetic motifs of anaerobic fungi in manure-fed digesters, in landfill sites and in pond and stream muds adjacent to land grazed by livestock [58-60].

Anaerobic fungi are known to produce a survival stage that can exist for many months in dried livestock faeces $[20,21,68]$. They can also be readily isolated in culturable form from livestock manure and slurries $[59,61]$. Most isolates of anaerobic fungi studied in the laboratory have been obtained from livestock faeces. Thus, it seems inevitable that genetic motifs of anaerobic fungi will be detected in bioreactors, landfill sites or aqueous ecosystems where livestock manures are deliberately or accidentally introduced. It is therefore necessary to conduct this type of research in accordance with Koch's postulates, to isolate, re-introduce and re-isolate viable cultures, before ascribing a role for anaerobic fungi in the AD environment, or indeed in any bioaugmentation study.

\subsubsection{Bioreactor Design and Habitat Engineering}

Many of the techniques used to culture anaerobic fungi in the laboratory are based on methods developed by Hungate [69], Bryant [70], Hungate and Macey [71], and Miller and Wolin [72]. With relatively few exceptions these methods, together with the enumeration 
and growth determining procedures of Joblin [41] and Theodorou et al. [43,73], are used to routinely culture and maintain anaerobic fungi at bench-scale in the laboratory. This subject area was reviewed recently by Haitjema et al. [37]. In general, anaerobic fungi are grown at $39^{\circ} \mathrm{C}$ without agitation in small batch cultures (of 10-100 mL culture volume) in thick-walled glass tubes or bottles sealed with gas-tight stoppers. In order to retain culture viability, anaerobic fungi must be maintained in sequential batch culture, with a transfer interval of between 2 and 7 days [37]. While some anaerobic fungi have been grown on defined media [74], better growth is obtained on complex media where sterile rumen fluid (10-15\%) is an essential component of all such media. Problems associated with culture viability and the requirement for rumen fluid in culture media are noteworthy as barriers to growing anaerobic fungi in larger-scale bioreactors. The need for rumen fluid is a particular constraint to scale-up and research is required to elucidate those factors in rumen fluid that are necessary to stimulate fungal growth.

The first attempt to grow anaerobic fungi on a plant biomass concentration that was higher than that typically used in batch cultures was performed by Zhu et al. [75,76]. In their research, by continuously eluting growing cultures with fresh culture medium, they succeeded in growing an anaerobic fungus on increasing concentrations, up to $80 \mathrm{~g}$ dry matter (DM) $\mathrm{L}^{-1}$ of wheat straw. By using a multichannel peristaltic pump to deliver fresh culture medium to several culture bottles as spent medium was removed, these authors were able to monitor replicated cultures and make treatment comparisons. When compared with results obtained from conventional batch cultures, where the fungus is grown on just $10 \mathrm{~g} \mathrm{DM} \mathrm{L}^{-1}$ of wheat straw, their continuous-flow cultures produced up to 20 times more cell wall-degrading enzymes (CMCase and $\beta$-glucosidase) [75]. In comparisons involving anaerobic fungi grown on $80 \mathrm{~g} \mathrm{DM} \mathrm{L}^{-1}$ of wheat straw in batch or continuous-flow cultures, up to 30 times more cell wall-degrading enzymes were produced [76]. While just $5-9 \%$ of the wheat straw DM was lost in batch cultures grown on $80 \mathrm{~g} \mathrm{DM} \mathrm{L}^{-1}$, during the same incubation period, 52-56\% was lost in comparable continuous-flow cultures [76]. The continuous-flow cultures described by Zhu et al. $[75,76]$, although not representative of conventional continuous-culture systems where substrate as well as culture medium is removed, provided a simple and effective means of growing anaerobic fungi on high concentrations of plant biomass approximating those found in the rumen. The authors concluded that by using media flushing to remove the build-up of toxic fermentation end-products, the fungus was able to degrade considerably more wheat straw, produce significantly larger quantities of plant biomass degrading enzymes and survive for significantly longer periods of time in continuous-flow as opposed to batch cultures. In their 1997 publication, Zhu et al. [76] concluded that anaerobic fungi and continuousflow cultures may have industrial potential. The effect of including in continuous-flow cultures, methanogenic and/or other non-methanogenic bacteria alongside anaerobic fungi offers intriguing possibilities and awaits further research. Important components of rumen fermentation, such as high DM concentrations, anaerobic conditions, selective retention of particulate matter, removal of toxic end-products and pulsed addition of substrate will need to be considered when developing suitable fermentation systems for the anaerobic fungi.

\subsubsection{Solid Substrate Fermentation}

Solid substrate fermentation is a process in which microorganisms ferment a substrate in the absence of free water or with a very low free water content $[77,78]$. Unlike bacteria, filamentous aerobic fungi are able to grow on a substrate in the absence of free water by utilising the bound water in the substrate $[79,80]$. Aerobic fungi which grow on lignocellulosic substrates tend to grow in a linear rather than exponential manner [81]. Industrial applications for microorganisms such as Trichoderma and Aspergillus involve submerged culture bioreactors, but these fungi have been highly adapted and genetically modified for this purpose $[82,83]$. In their natural habitat, these fungi grow on solid substrates and are not submerged in culture media. Under these circumstances, and in this particular 
niche, the fungi require different enzymes, cellular structures and metabolites to those grown in submerged culture [84-86]. In recent years, there has been much interest in harnessing aerobic fungi for the purpose of solid substrate fermentation [78] and some of the adopted approaches may be applicable to the anaerobic fungi. Figure 2 presents, in schematic format, bioreactor designs that may be suitable for industrial-scale use of anaerobic fungi. While noting that the zoospores of anaerobic fungi exist in a liquid environment, their vegetative thalli grow directly on insoluble substrates and it may therefore be possible to adapt existing solid substrate fermentation methodologies to grow anaerobic fungi at industrial scale. The culture systems commonly used for solid substrate fermentation in industry are static bioreactors (fixed bed and perforated trays), agitated bioreactors (horizontal drum, continuously/intermittently pulsed) and mixing bioreactors (rotating drum) [78].

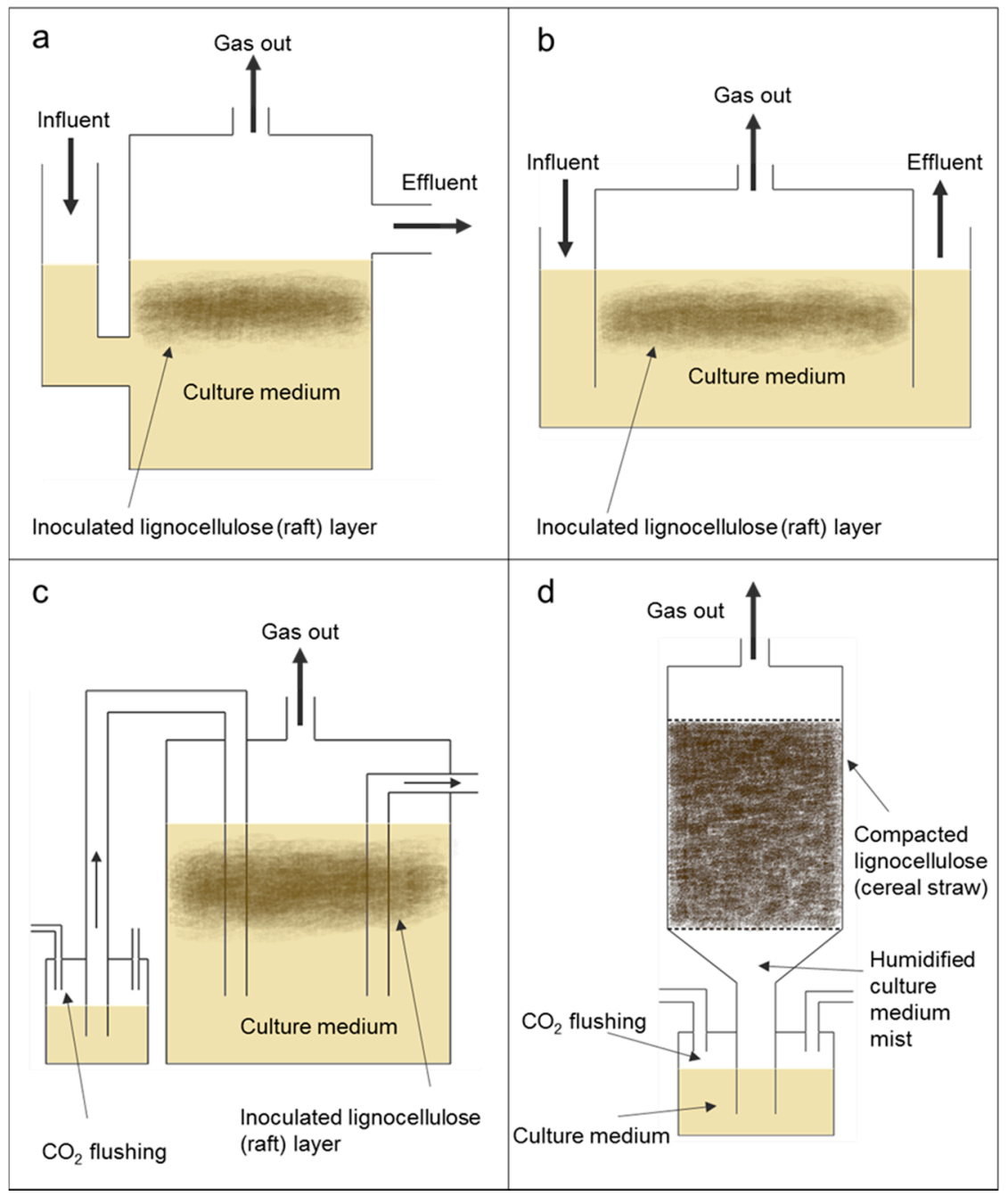

Figure 2. Schematic bioreactor and anaerobic digester designs for industrial-scale use of anaerobic fungi. A lignocellulose (raft) layer forms due to biomass floating as anaerobic fungi ferment their substrate: (a) up-flow anaerobic digester where anaerobic fungi are grown \pm methanogens to produce $\mathrm{CH}_{4}, \mathrm{H}_{2}$ and $\mathrm{CO}_{2}$; (b) plug flow anaerobic digester; (c) continuous-flow bioreactor with intermittent substrate feeding; and (d) high dry matter (solid-state) bioreactor where anaerobic fungi \pm methanogens grow directly on moist substrate. The bioreactor is flushed with $\mathrm{CO}_{2}$ humidified with culture medium. Substrate is batch fed and residual lignocellulose can be used downstream in biotechnological processes. 
In comparison to submerged culture, solid substrate fermentations are less susceptible to bacterial contamination as most bacteria require a liquid environment in order to grow and/or form a biofilm on the surface of a substrate [78,87]. Hydrolytic enzymes in solid state fermentation systems are also less prone to substrate inhibition [78,87]. If secondary metabolites, enzymes or free sugars are the desired end-product in a solid-state fermentation, then the highly concentrated effluent produced serves to eliminate the need for costly additional downstream concentration steps [78,87]. By contrast, submerged fermentation has the advantages of easier control of parameters such as $\mathrm{pH}$, temperature and separation of substrate from end products [88]. As many of the existing designs of solid-substrate fermenters are unsealed to the atmosphere, maintaining a strictly anaerobic environment will be a key challenge associated with adapting solid substrate fermentation for use with anaerobic fungi. Additionally, the absence of a liquid medium presents further challenges as the buffering capacity of the growth medium and the absence of reducing agents present the risk of oxygen toxicity killing the fungus. Nevertheless, it might be feasible to develop a continuous culture system based on a plug flow digester with a very high solids content, suspended in a highly concentrated growth media, similar to the bench-scale continuous-flow systems investigated by Zhu et al. [75,76].

\subsection{Genetic Engineering}

Anaerobic fungi have large genomes ( 100-200 Mb) adapted for utilisation of plant matter and survival in the gastrointestinal tract of herbivorous mammals [37,89]. Solomon et al. [4] found that fungi obtained from horse, sheep and goat contained more genes encoding carbohydrate active enzymes (CAZymes) than any other microorganism. Many of these CAZymes are found in large multiprotein cellulosomes that allow the fungus to break down lignocellulosic biomass in a synergistic manner [37]. Despite historical and recent progress in this field, the composition of these extracellular enzyme-cellulosome complexes is not well described, and it is unclear whether fungal cellulosomes are predominantly secreted or bound to rhizoidal or bulbous structures [37,90,91]. With fungal genetic engineering to manipulate product selectivity and yields, anaerobic fungi show great potential for one-step processing of crude biomass. Realisation of this goal will require the development of robust genetic tools for anaerobic fungi (Figure 3). In parallel, the unique and diverse arsenal of enzymes used by these organisms [4] has spurred efforts to express native fungal genes in other hosts (heterologous expression).

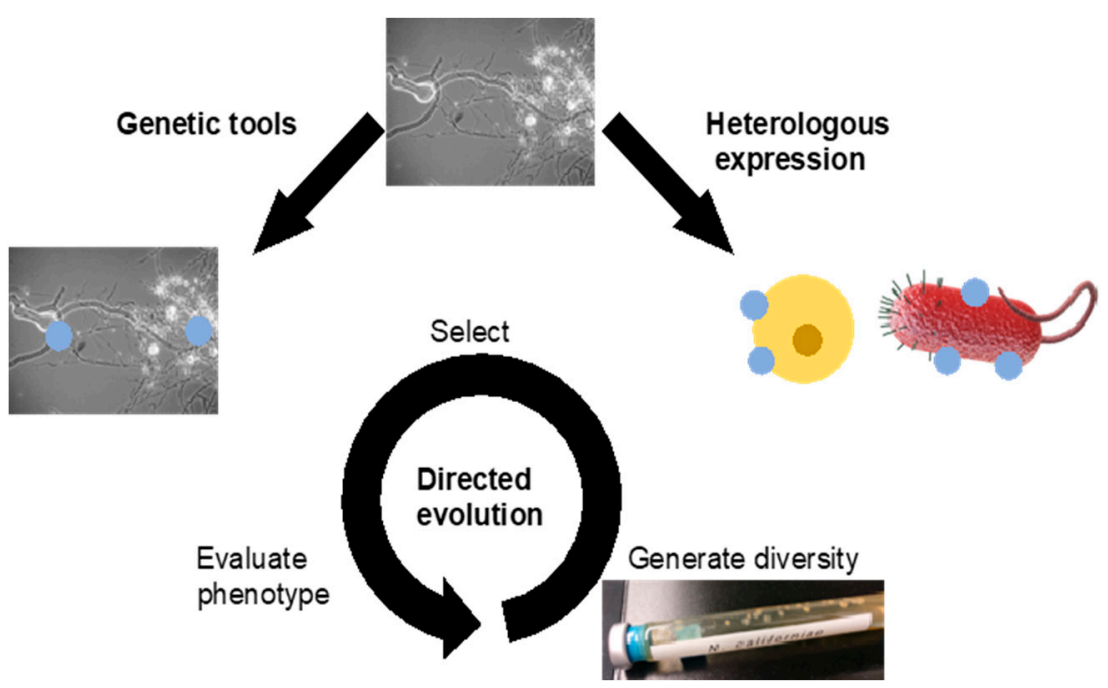

Figure 3. Anaerobic fungi show great potential for new genetic tool development and heterologous expression for biofuels production. Blue dots represent inserted or modified proteins, e.g., a fluorescent reporter attached to a knock-in cellulase. Fungi or heterologous hosts can be evolved for improved phenotypes, such as $\mathrm{H}_{2}$ production. 
As a framework for investigation, Wilken et al. developed a genome-scale metabolic model for N. lanati, an anaerobic gut fungus isolated from sheep faeces [74]. This model was validated by ${ }^{13} \mathrm{C}$ metabolic flux analysis that identified the fluxes of carbon through glycolysis, tricarboxylic acid cycle, and in the hydrogenosome. For improved $\mathrm{H}_{2}$ production, future genetic engineering efforts may focus on directing flux through the hydrogenosome. This organelle and the pathways within it are not well characterised, with pyruvate ferredoxin oxidoreductase and/or pyruvate formate lyase potentially playing important roles in $\mathrm{H}_{2}$ production [74]. Future development of enzyme knockout strains can validate critical pathways and enable strain screening and evaluation to yield more productive enzyme and organism variants. Other potential biofuel targets include ethanol and butanol, produced by engineering strains with modified alcohol dehydrogenase and aldehyde dehydrogenase activities. Increased production of volatile fatty acids may also be beneficial when paired with other microorganisms to produce biofuels.

\subsubsection{Transformation}

The obligately anaerobic nature and complex life cycle [92-94] are challenges towards genetic engineering of these fungi. There have been no reports of stable genetic transformation of anaerobic fungi so far. Transformation requires foreign DNA entry into the organism and either integration into host genomic DNA or maintenance through replicating structures such as plasmids or artificial chromosomes.

Given the expected low transformation efficiency of the techniques described here, it will be important to use a robust selection marker. The first report of transformation on an anaerobic fungus described transient expression of the $\beta$-glucuronidase gene under control of a putative enolase promoter using a biolistic device (gene gun) approach [95]. However, these experiments were conducted without any selection pressure for the delivered gene, and the blue pigment generated upon treatment with substrate post-transformation failed to appear 7 days after transformation. Anaerobic fungi have been reported to be sensitive to hygromycin B [96], and transformation with a resistance marker can potentially be a useful selection scheme. A scheme using the hph gene encoding a hygromycin B phosphotransferase is the most common selection method used in filamentous (aerobic) fungi [97]. Investigation into anaerobic fungal autotrophs can also be fruitful, as it would enable complementation strategies. The wild type strains of yeasts such as Saccharomyces pombe, $S$. cerevisiae and Candida albicans are sensitive to 5-Fluoroorotic Acid (5-FOA) due to native expression of orotidine-5-monophosphate decarboxylase (OMP decarboxylase, encoded by the URA3 gene). In yeasts, URA3 is involved in uracil biosynthesis, and URA3-deficient strains are dependent on uracil supplementation for growth. Anaerobic fungi can be grown in defined media without uracil supplementation [98] and published genomes contain a putative OMP decarboxylase $[4,37,89]$, and are therefore likely to be sensitive to 5-FOA. A strategy involving knockout of the URA3 homologue and selection with 5-FOA merits further investigation for selection.

Due to the fact that the vegetative thallus in monocentric anaerobic fungi is devoid of DNA and because fungal zoospores are reported to have relatively thin, non-chitinaceous, flexible cell walls [99], zoospores have been targeted as the most amenable life cycle stage for nucleic acid delivery and strain engineering. Calkins et al. [100] described a protocol to harvest zoospores from Pecoramyces ruminantium and later showed RNA interferencemediated knockdown of lactate dehydrogenase [101]. RNA interference (RNAi) has been observed naturally and is used in many organisms to decrease mRNA transcript number (and thus protein number) of targets [102]. Calkins and co-workers [101] identified genes required for RNAi in the genome of P. ruminantium and synthesised doubled-stranded RNA encoding a 21 base pair stretch in the lactate dehydrogenase transcript. They incubated this RNA with harvested zoospores and observed significant decreases in target gene expression ( $25 \%$ of untreated) and lactate production ( $14 \%$ of untreated) in propagated fungal mass. This work represents a promising proof-of-concept of metabolic engineering in anaerobic fungi and opens several interesting avenues of exploration. However, accompanying 
lactate dehydrogenase downregulation was an unwanted and non-specific downregulation of an additional 29 transcripts. Additional mechanistic investigation of siRNA targeting is needed, including understanding the duration of effect and generalisability to other genes and pathways.

A recent report by Swafford et al. [103] details the electroporation of the closely related blastoclades Batrachochytrium dendrobatidis and B. salamandrivorans. Electroporation is a widely used method of genetic transformation, in which target cells are exposed to a high electric field (typically $250-3000 \mathrm{~V} / \mathrm{cm}$ ) in the presence of DNA. The electric field is thought to cause temporary holes in the cell membrane and subsequent entry of DNA [103]. In the study by Swafford and colleagues, electroporation parameters (pulse shape, voltage and timing) were optimised for dextran entry and viability, resulting in $95 \%$ of zoospores taking up payload and a $41-71 \%$ survival rate, quantified by flow cytometry and motility, respectively. The authors observed that even without electroporation, some zoospores exhibited pericellular fluorescence due to dextran cell wall interactions, and analysis of electroporated cells showed intracellular signal, confirming uptake. Additionally, the authors note that the electroporation efficiency was highly dextran source-dependent, which has implications for extension to DNA transformation. Assembly of nucleic acids into polyplexes, as applied in the gene therapeutics field [104], may be necessary for high efficiency transformation of anaerobic fungi. Furthermore, uptake and persistence of DNA is dependent on long-term survival and division, and it is possible that electroporated zoospores may survive initially but fail to encyst and propagate. Careful quantification of zoospore propagation, through thallus forming unit (TFU) determinations [39], or gas pressure measurements [73], will be important for protocol validation especially when generating large and diverse gene libraries.

Other methods for nucleic acid delivery into non-model organisms are worth further exploration in their application to anaerobic fungi. Agrobacterium tumefaciens is a natural plant-targeting bacterium that has been used to integrate DNA into filamentous fungi, like Aspergillus. This system has been used to insert DNA into specific regions in the host DNA via CRISPR/Cas9. However, Agrobacterium-mediated transformation requires extended $\left(>36 \mathrm{~h}\right.$ ) co-incubation at temperatures below $30^{\circ} \mathrm{C}$, whereas Neocallimastix grows best at $39^{\circ} \mathrm{C}$, and is capable of growth only between $33^{\circ} \mathrm{C}$ and $41^{\circ} \mathrm{C}$ [105]. The reconciliation of growth conditions is a necessary first step for developing a general Agrobacterium-mediated transformation protocol for anaerobic gut fungi.

\subsubsection{Heterologous Expression}

While there is a growing effort to directly genetically manipulate anaerobic fungi, the challenges posed by these non-model organisms make the expression of genes of interest in model systems, like Escherichia coli and S. cerevisiae, appealing. A comprehensive list of reports of heterologous expression of anaerobic fungal proteins is available in Flad et al. [3]. Jones et al. [18] reported the expression and structural characterisation of anaerobic fungal glycoside hydrolases in E. coli, finding that arabinose-containing disaccharides were released by enzymatic digestion of plant-derived arabinan and arabinoxylan. In 2011, Jin reported the heterologous expression of endo- $\beta$-1,4-glucanase (EG) from an Orpinomyces strain in T. reesei [106]. Importantly, this required codon optimisation of the natively AT-rich anaerobic fungal gene. Wilken et al. describe a codon optimisation table, as well as amino acid and nucleotide-level abundance profiling of several fungal genomes, which would warrant consideration for construct design and engineering strategy development [107]. Seppälä et al. [108] expressed fluoride exporter proteins from several Neocallimastix strains in S. cerevisiae and found a higher activity variant than the wild type S. cerevisiae exporter, contributing to a higher fluoride tolerance.

Despite the rapid pace of progress in the heterologous expression of fungal enzymes, the complex, yet biotechnologically valuable anaerobic fungal cellulosome has yet to be expressed in a model organism, although en route to synthetic fungal cellulosome construction, dockerin-fused fungal enzymes have been expressed in yeast and E. coli [90]. 
Many heterologous proteins sourced from anaerobic fungi struggle to achieve soluble expression in model microbes, even after careful codon optimisation. This may be due to the inability of native-like post-translational modifications in the heterologous host, activation of stress responses in the host, or both [109]. Insertion of anaerobic fungal genes in currently more genetically tractable organisms can enable the use of typical protein engineering techniques such as directed evolution and structure-aided design. The creation of large protein libraries in S. cerevisiae and E. coli, in some cases exceeding $10^{8}$ variants, makes the high throughput screening of variants possible. Once an optimal variant is identified, it can be further refined and potentially retro-inserted into the original host, completing the development cycle. This methodology may be particularly relevant for anaerobic fungi, which are exceptional lignocellulosic degraders, but not highly genetically tractable, towards efficient production of biofuels.

\section{Emerging Opportunities for Industrial Biofuel Production}

The structure of lignocellulose and associated challenges relating to enzymatic access and hydrolytic degradation of its constituent polymers have been discussed frequently in the scientific literature (see, e.g., in $[1,2])$. Anaerobic fungi are considered to have good potential for use in a range of lignocellulosic biofuel production processes due to their natural vast array of CAZymes and repertoire of fermentation products which can be used either directly as fuel or as biofuel precursors $[4,89]$. The arsenal of lignocellulose degradation enzymes expressed by anaerobic fungi includes cellulases, $\beta$-glucosidases, hemicellulases, endoglucanases, exoglucanases and esterases $[4,110]$. However, it is not just the possession of an abundance of CAZymes that enable anaerobic fungi to efficiently degrade lignocellulosic substrates but also because their enzymes are selectively tethered to a large multi-protein complex, the cellulosome $[4,37]$. The ability to assemble, regulate and deploy CAZymes within a protein scaffold enables precision orientation of their catalytic domains towards the heterologous lignocellulosic substrates. Haitjema et al. [37] considers that the fungal cellulosome is an evolutionary chimeric structure that has evolved in anaerobic fungi by co-opting useful activities from bacterial neighbours within the gut microbiome.

This section introduces and discusses various scenarios in which anaerobic fungi could be utilised for lignocellulosic biofuel production. This includes consideration towards the use of anaerobic fungi in biological pretreatments and for consolidated bioprocessing purposes. Emphasis is placed on the assertion that anaerobic fungi perform dark fermentation and envisage their integration with emerging biofuel production systems.

\subsection{Biological Pretreatment}

Relatively few microorganisms can enzymatically deconstruct lignocellulosic substrates. Consequently, numerous microorganisms which have been identified as candidates for the production of biofuels, are unable to make use of the carbohydrates in lignocellulose without a pretreatment stage. Examples of such microorganisms include naturally occurring ethanologens, S. cerevisiae and Zymomonas mobilis, both of which lack cellulolytic activity [111].

Pretreatments are often energy-intensive or utilise potentially hazardous chemicals. At present, the use of lignocellulose material for biofuel production remains severely restricted due to the lack of effective, low-cost and environmentally friendly pretreatments [1,2]. In recent years, biological hydrolysis has begun to emerge as being potentially suitable for pretreatment purposes. Biological pretreatments can be divided into either the targeted use of hydrolytic enzymes extracted from culture broths or enzymatic hydrolysis during in situ microbial growth [112]. Most biological hydrolysis pretreatments to date have focused on the utilisation of aerobic fungi and their enzymes to degrade lignocellulose constituents [113-116]. According to Solomon et al. [4], the enzymatic repertoire of anaerobic fungi is superior to that of aerobic fungi, making them good candidates for use in biological pretreatment processes. 
From the current literature, biofuels have yet to be produced at scale from lignocellulose hydrolysates created by pretreatments using enzyme cocktails derived from anaerobic fungi. However, Morrison et al. [117] reported the first use of an enzyme cocktail from an anaerobic fungus and successfully applied it to partially hydrolyse acid, alkali or ionic liquid treated corn stover and switch grass. A number of more recent studies have used in situ anaerobic fungal pretreatment of lignocellulose to improve biofuel production. Ranganathan et al. [118] tested the sequential growth of P. ruminantium and E. coli for the production of bioethanol from alkali pretreated corn stover. The anaerobic fungus was cultured on corn stover for $48 \mathrm{~h}$ before the addition of cycloheximide to inhibit growth. The authors reported that inhibition of the fungus resulted in the accumulation of free sugars from corn stover due to continued activity of residual enzymes derived from the fungus. After 14 days of saccharification, the biomass was inoculated with the ethanologenic E. coli strain KO11 and the authors reported a conversion efficiency of $14.1 \%$ of corn stover into bioethanol [118]. The investigators showed that the anaerobic fungal pretreatment was suitable for solubilisation of $9.91 \%, 17.19 \%$ and $10.6 \%$ of the fermentable sugars in switchgrass, sorghum forage and energy (sugar) cane, respectively [118]. Dollhofer et al. [63] performed a 7-day pretreatment of $N$. frontalis growth on hay before Clostridia dominated anaerobic digestion to produce biogas. The investigators found that the $N$. frontalis pretreatment significantly increased the rate of biogas production during anaerobic digestion [63]. Ferraro et al. [64] carried out a 72-h pretreatment on mushroom-spent wheat straw by using a microbial community that contained a pool of fermentative bacteria with and without two strains of anaerobic fungus. The authors concluded that the presence of Neocallimastix sp. and Orpinomyces sp. in the pretreatment improved the average yield of biomethane production from the mushroom spent wheat straw from $66.9 \mathrm{NmL}^{-\mathrm{CH}_{4}}$ g-volatile-solid(VS) ${ }^{-1}$ to $117 \mathrm{NmL}^{-\mathrm{CH}_{4}} \mathrm{~g}^{-\mathrm{VS}^{-1}}$.

The mechanism of enzymatic hydrolysis of lignocellulose by anaerobic fungi differs from that carried out by aerobic fungi. Aerobic fungi secrete free enzymes into their extracellular environment. In contrast, anaerobic fungi predominately synthesise cellulosome complexes which accommodate a multiplicity of interchangeable plant cell wall-degrading enzymes; this complex remains tethered to the cell membranes of their hyphae [119]. The physical attachment of cellulosome structures to rhizoid tips [120] may facilitate targeted localisation of CAZymes to their substrate. These attributes translate to potential benefits in hydrolysis times achieved by in situ growth of anaerobic fungi during the pre-treatment stage. Additionally, Hatakka [115] demonstrated that the supplementation of additional oxygen can reduce the pretreatment time required by aerobic fungi. The absence of any need for oxygen to facilitate growth of the anaerobic gut fungi (or the activity of their enzymes) has the potential to remove the costs and challenges associated with aeration of growth chambers.

A key disadvantage of in situ growth of fungi for pre-treatment purposes is the loss of feedstock carbohydrates to uptake, growth and cellular activity by the pretreatment microorganism, which causes a decrease in potential product yields from the receiving biofuel producing organism [121]. In addition, the accumulation of free sugars has been shown to repress the degradation of lignocellulose by anaerobic fungi $[4,122,123]$. If anaerobic fungi are to be used as an effective pretreatment, then a system to remove the hydrolysed sugars from the environment must be employed to limit their consumption by the fungus to what is essential for maintenance and to mitigate catabolite repression of their hydrolytic proteins. An alternative strategy to pretreatment is to develop the use of anaerobic fungi for consolidated bioprocessing and thus take advantage of their own capability to convert lignocellulose into bioethanol and biohydrogen fuels.

\subsection{Consolidated Biofuel Production}

Consolidated bioprocessing of lignocellulose into biofuels is the process of simultaneous saccharification of polysaccharides and the fermentation of solubilised sugars in a single bioreactor, ideally by a single microorganism. Consolidated bioprocessing is poten- 
tially advantageous over the use of a separated pretreatment stage for a number of reasons. First, the continual fermentation of newly solubilised sugars avoids their accumulation in the environment and the associated risk of product inhibition of CAZymes [91]. Second, the additional financial costs associated with equipment and operation of multiple bioreactors can be saved. Third, if a single species can be utilised and optimised for bioprocessing, then this provides a potential opportunity to achieve a higher ratio of biofuel to microbial biomass and thus greater specific product yields.

\subsubsection{Bioethanol Production}

The potential use of anaerobic fungi for the consolidated production of bioethanol is worth exploring due to the combination of their CAZyme and cellulosome resources, an ability to utilise both $5 \mathrm{C}$ and $6 \mathrm{C}$ carbohydrates and their possession of ethanologenic metabolism [124]. It has been shown that a range of lignocellulose-containing substrates (e.g., wheat straw [124], bagasse [124], barley straw [6], energy cane [118], sorghum forage [118] and corn stover [118]) can be converted to bioethanol by anaerobic fungi. Examples of bioethanol production by anaerobic fungi are presented in Table 1, which has been compiled to give a limited overview of the variable and typically low concentrations produced that have been reported to date. Historically, the production of ethanol by anaerobic fungi has been reported when the metabolic flow of carbon has not been considered during fermentation studies designed to optimise the digestibility of forage, and for which the main objective was not the production of bioethanol. This lack of optimisation could be a contributing factor, explaining why bioethanol yields from anaerobic fungi are low in comparison to those from filamentous fungi such as Fusarium oxysporum [111] or T. reesei [125]. A key advantage for anaerobic fungi (over F. oxysporum or T. reesei) is not just their CAZyme repertoire but also their ability to carry out both lignocellulose degradation and bioethanol production in the absence of oxygen. This latter characteristic removes the need for intermittent switches between aerobic and anaerobic conditions within an industrial-scale bioreactor, which has previously been identified as problematic for maintaining upkeep of obligately aerobic fungi [125].

Although anaerobic fungi represent an interesting opportunity for the industrial consolidated production of bioethanol from lignocellulose, a number of challenges must be resolved to sufficiently improve the process. One prospective challenge is the product inhibition of anaerobic fungal growth that can be caused by the accumulation of ethanol [126]. The kinetic product inhibition constant for ethanol in relation to the growth of $N$. frontalis on cellulose was reported to be $222 \mathrm{mM}$ (or $10.2 \mathrm{mg} \mathrm{L}^{-1}$ ) [126]. For comparison, half of the maximum ethanol product inhibition for $S$. cerevisiae has been shown to occur in ethanol concentrations of between 10 and $20 \mathrm{~g} \mathrm{~L}^{-1}$. Current challenges faced by consolidated bioprocessing of ethanol by anaerobic fungi include low and variable ethanol yields (Table 1) and the preferable formation of alternative fermentation end-products (e.g., formic acid, acetic acid and lactic acid) [126]. Potential avenues for overcoming these obstacles include upregulation, heterologous expression, induced mutations or selective pressure of genes relating to ethanol production or tolerance. There has been success in the use of some of these techniques for improving ethanol yields in aerobic fungi. For example, Stevenson and Weimer [127] isolated a strain of Trichoderma from cow dung and improved bioethanol production from cellulose from approximately $0.4 \mathrm{~g}$ ethanol $\mathrm{L}^{-1}$ to $2 \mathrm{~g}$ ethanol $\mathrm{L}^{-1}$. The authors achieved this increase after inducing mutations, facilitating parasexual fusion and increasing the availability of $\mathrm{O}_{2}$, although the actual cause for the increase was undetermined [127]. In another study, overexpression of the carbohydrate membrane transporter $H x \mathrm{t}$ in F. oxysporum caused a 39\% increase in consolidated bioethanol production from a mixture of wheat straw and bran [128]. By comparison, the development of anaerobic fungi for the purpose of consolidated bioethanol production remains a relatively understudied topic. 
Table 1. Ethanol production by anaerobic fungi.

\begin{tabular}{|c|c|c|c|}
\hline Fungal Isolate & Substrate & $\begin{array}{l}\text { Ethanol Yield } \\
{\left[\mu \mathrm{mol} \mathrm{g}^{-\mathrm{L}]}{ }^{*}\right.}\end{array}$ & Reference \\
\hline Piromyces sp., isolate E2 & Cellobiose & 50 & [124] \\
\hline Piromyces sp., isolate E2 & Glucose & 80 & [124] \\
\hline Piromyces sp., isolate E2 & Fructose & 80 & [124] \\
\hline Piromyces sp., isolate E2 & Mannose & 80 & [124] \\
\hline Piromyces sp., isolate E2 & Lactose & 14.77 & [124] \\
\hline Piromyces sp., isolate F1 & Xylose & 1920 & [129] \\
\hline Piromyces sp., isolate E2 & Xylose & 113 & [124] \\
\hline Piromyces sp., isolate E2 & Xylan & 84 & [124] \\
\hline$N$. frontalis & Cellulose & 2310 & [5] \\
\hline N. frontalis & Cellulose & 3750 & [130] \\
\hline Piromyces sp., isolate E2 & Cellulose & 157 & [124] \\
\hline Piromyces sp., isolate E2 & Wheat straw & 695 & [124] \\
\hline Piromyces sp., isolate E2 & Wheat bran & 891 & [124] \\
\hline Piromyces sp., isolate E2 & Starch & 157 & [124] \\
\hline Pecoramyces ruminantium & Switch grass $* *$ & 540 & [118] \\
\hline P. ruminantium & Energy cane ${ }^{* *}$ & 510 & [118] \\
\hline P. ruminantium & Sorghum ** & 560 & [118] \\
\hline P. ruminantium & Mixed prairie $* *$ & 490 & [118] \\
\hline P. ruminantium & Corn stover ** & 1030 & [118] \\
\hline
\end{tabular}

*Values quoted are with zero decimal places. ${ }^{* *}$ Substrates were pretreated with $3 \% \mathrm{NaOH}$. All substrates were autoclaved prior to fermentation and fermented in batch culture.

\subsubsection{Dark Fermentation}

To date, the potential uses of anaerobic fungi in industrial biogas production processes has been researched and discussed in the context of converting lignocellulose into precursors for biomethane production. Combining the growth of anaerobic fungi with methanogenic organisms to ultimately produce biomethane has been reviewed in detail by Dollhofer et al. [120]. However, the use of axenic cultures of anaerobic fungi to produce biohydrogen as an alternative to the symbiotic production of biomethane from lignocellulose has not been considered. The use of biohydrogen could be advantageous over biomethane in terms of fuel efficiency. This is because hydrogen has a higher heating value (HHV) of $141.9 \mathrm{~kJ} \mathrm{~g}^{-1}$ [131]. In comparison the HHV of methane is $61 \%$ lower at $55.5 \mathrm{~kJ} \mathrm{~g}^{-1}$ [131]. At present, the global production and consumption of $\mathrm{H}_{2}$ is approximately $70 \mathrm{Mt} \mathrm{year}^{-1}$ [132]. The gas is almost exclusively derived from reforming of fossil fuels and production causes $830 \mathrm{Mt}$ of net $\mathrm{CO}_{2}$ emissions, annually [132]. Therefore, one of the barriers to a sustainable global $\mathrm{H}_{2}$ economy is the requirement for a low-cost, green method of production such as biological generation from lignocellulosic biomass. The use of anaerobic fungi for this purpose, with their hydrogen generating hydrogenosomes and unrivalled ability to deconstruct lignocellulosic substrates, merits detailed scientific exploration. Previously, the anaerobic production of $\mathrm{H}_{2}$ by bacteria or algae in the absence of light has been collectively referred to as "dark fermentation" [133,134]. Herein, and for the first time, the term dark fermentation is used while discussing the potential for industrial fermentative biohydrogen production by anaerobic fungi.

The production of $\mathrm{H}_{2}$ by axenic cultures of anaerobic fungi was first reported by Bauchop and Mountfort [5]. In that study, an anaerobic fungus from the ovine rumen was grown on cellulose in the presence and absence of methanogenic archaea. In the absence of methanogens, the authors reported $\mathrm{H}_{2}$ yields of $0.353 \mathrm{~mol}-\mathrm{H}_{2}$ mol-hexose ${ }^{-1}$. Since the initial observations of Bauchop and Mountfort [5], the production of $\mathrm{H}_{2}$ has been detected during the growth of a range of anaerobic fungal species (Table 2).

Anaerobic fungi produce $\mathrm{H}_{2}$ in membrane-bound organelles known as hydrogenosomes [135]. Hydrogenosomes produce $\mathrm{H}_{2}$ gas by using protons as electron acceptors during mixed-acid fermentation of monomeric sugars (predominantly glucose and xylose) derived from cellulose and hemicellulose, to generate ATP. The reduction of protons is 
catalysed in the hydrogenosome by hydrogenase enzymes which are known to be highly sensitive to product inhibition by $\mathrm{H}_{2}[135,136]$. In their natural habitat in the mammalian digestive tract, the accumulation of $\mathrm{H}_{2}$ is limited due to consumption and conversion by methanogens [137]. Therefore, methanogenesis is likely to facilitate the activity of hydrogenase and generation of $\mathrm{H}_{2}$ and ATP by anaerobic fungi [135].

Currently, the relationship between the partial pressure of $\mathrm{H}_{2}$ in the environment and metabolic shifts by anaerobic fungi, away from hydrogenosome fermentation pathways, has not been fully elucidated $[129,138]$. It is known that in the absence of $\mathrm{H}_{2}$-consuming organisms, anaerobic fungi increase production of alternative electron sinks to $\mathrm{H}_{2}$ (e.g., lactate, ethanol and succinate) $[66,139,140]$ and suppress lignocellulose deconstruction $[5,6,66,138,139,141-145]$. Previous observations of reduced lignocellulose hydrolysis are supported by recent transcriptomic analysis which revealed that Anaeromyces robustus downregulated overall CAZyme production when grown axenically in comparison to when co-cultured with Methanobacterium bryantii [144]. Furthermore, $\mathrm{H}_{2}$ has previously been observed to inhibit the growth of a range of other fermentative microorganisms [136,146-148]. Therefore, it is hypothesised that the accumulation of $\mathrm{H}_{2}$ limits dark fermentation $\mathrm{H}_{2}$ yields from anaerobic fungi and that their industrial growth in the absence of $\mathrm{H}_{2}$-consuming species will require the integration of suitable technical solutions for in situ $\mathrm{H}_{2}$ removal.

Table 2. Anaerobic fungal $\mathrm{H}_{2}$ yields from dark fermentation.

\begin{tabular}{cccc}
\hline Fungal Isolate & Substrate & $\begin{array}{c}\mathbf{H}_{\mathbf{2}} \text { Yield } \\
{\left[\boldsymbol{\mu \mathbf { m o L }} \mathbf{~ g}^{\mathbf{- 1}} \mathbf{}^{*}\right.}\end{array}$ & Reference \\
\hline $\begin{array}{c}\text { Piromyces sp., isolate E2 } \\
\text { Neocallimastix sp., isolate R1 }\end{array}$ & Cellobiose & 54 & {$[124]$} \\
Piromyces sp., isolate F1 & Glucose & 3464 & {$[105]$} \\
Piromyces sp., isolate E2 & Glucose & $\approx 377 * * *$ & {$[138]$} \\
Piromyces sp., isolate E2 & Glucose & 70 & {$[124]$} \\
Piromyces sp., isolate E2 & Fructose & 161 & {$[124]$} \\
Piromyces sp., isolate E2 & Lactose & 106 & {$[124]$} \\
Piromyces sp., isolate E2 & Mannose & 88 & {$[124]$} \\
Neocallimastix sp., isolate R1 $* *$ & Xylose & 106 & {$[124]$} \\
N. frontalis & Xylose & 8020 & {$[105]$} \\
Sphaeromonas communis & Cellulose & 2177 & {$[5]$} \\
Neocallimastix sp.,isolate N1 & Cellulose & 2880 & {$[143]$} \\
Neocallimastix sp., isolate N2 & Cellulose & 2520 & {$[66]$} \\
Piromyces sp., isolate E2 & Cellulose & 2600 & {$[66]$} \\
Piromyces sp., isolate R1 & Cellulose & 2220 & {$[66]$} \\
Piromyces sp., isolate E2 & Cellulose & 2460 & {$[124]$} \\
N. frontalis & Cellulose & 159 & {$[141]$} \\
Piromyces sp., isolate E2 & Xylan & $\approx 2381 * * *$ & {$[124]$} \\
Piromyces sp., isolate E2 & Wheat Straw & 2261 & {$[124]$} \\
Piromyces sp., isolate E2 & Wheat bran & 1370 & {$[124]$} \\
N. frontalis. & Bagasse & 1957 & {$[149]$} \\
Piromyces sp., isolate E2 & Poplar wood chips & $1984 * * *$ & {$[124]$} \\
\hline
\end{tabular}

*Values quoted are with zero decimal places. ${ }^{* *}$ Neocallimastix sp., isolate R1 was classified N. hurleyensis [150] and subsequently reclassified as $N$. frontalis [151]. ${ }^{* *}$ Calculated on assumption that $\mathrm{H}_{2} \mathrm{~mL}$ reported in referenced paper was stated at $1 \mathrm{~atm}$. All substrates were autoclaved prior to fermentation and fermented in batch culture.

There are a number of technologies which have been applied at lab-scale to dark fermentation by bacteria to decrease product inhibition by $\mathrm{H}_{2}$ and significantly increase $\mathrm{H}_{2}$ production. Research in this area is ongoing but examples of these technologies include particular mixing regimes [152], gas sparging [153], ultrasonication [154], gas separation by membranes [155], the maintenance of low-pressure fermentation environments [156] and electrochemical removal [157]. For example, Mizuno et al. [153] demonstrated that the $\mathrm{H}_{2}$ yield from anaerobic communities growing on glucose could be increased from 0.85 mol- $\mathrm{H}_{2}$ mol-hexose ${ }^{-1}$ to $1.43 \mathrm{~mol}^{-\mathrm{H}_{2}}$ mol-hexose ${ }^{-1}$ by using a flow of $\mathrm{N}_{2}$ gas to continuously sparge the fermentation system. Other investigators have reported com- 
parable improvements to $\mathrm{H}_{2}$ yields when sparging with $\mathrm{CO}_{2}$ [158]. In another study by Niño-Navarro et al. [152], it was reported that a selection between the use of two common impeller designs resulted in a greater than 2-fold increase in fermentative $\mathrm{H}_{2}$ productivity which the authors attributed to mass transfer of $\mathrm{H}_{2}$ gas from the liquid phase. More recently, Ramírez-Morales et al. [155] successfully implemented the use of polymeric membranes to separate $\mathrm{H}_{2}$ from the headspace gas created during fermentation by a microbial consortium native to tobacco wastewater. Operation of their novel membrane bioreactor caused a $16 \%$ rise in $\mathrm{H}_{2}$ production [155]. The development and application of $\mathrm{H}_{2}$ removal technologies to the growth of anaerobic fungi (in the absence of methanogenic archaea) is an area of research which requires scientific attention to assure that the maximum potential of these organisms for $\mathrm{H}_{2}$ production can be fully realised.

The yield of $\mathrm{H}_{2}$ from dark fermentation by other microorganisms is known to be significantly influenced by many other parameters including feedstock type, feedstock concentration, $\mathrm{pH}$, temperature and species. Thus far, the reported production values for $\mathrm{H}_{2}$ from dark fermentation by anaerobic fungi remain low (Table 2). For example, the highest anaerobic fungal $\mathrm{H}_{2}$ yield from glucose of $3464 \mu \mathrm{mol} \mathrm{g}^{-1}\left(0.624 \mathrm{~mol}-\mathrm{H}_{2}\right.$ mol-hexose $\left.{ }^{-1}\right)$ [105] is towards the lower end of the typical range of between 0.57 and 2.80 mol- $\mathrm{H}_{2}$ mol-hexose ${ }^{-1}$ reported for bacterial dark fermentation [159]. Notably, anaerobic fungal $\mathrm{H}_{2}$ yields of

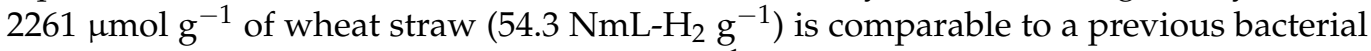
study that achieved a yield $58.78 \mathrm{NmL}-\mathrm{H}_{2} \mathrm{~g}^{-1}$ of alkaline pretreated wheat straw that had been supplemented with enzymes [160]. The current lack of process optimisation presents significant scope for $\mathrm{H}_{2}$ yield improvement from anaerobic fungi. Furthermore, a number of avenues exist to add further value to dark fermentation by making use of the soluble fermentation end-products via their biological conversion into additional $\mathrm{H}_{2}$ or $\mathrm{CH}_{4}$ biofuels.

\subsection{Biofuel Production from Dark Fermentation Products}

In addition to $\mathrm{H}_{2}$ and $\mathrm{CO}_{2}$ gases, anaerobic fungi have the capability to secrete a range of organic acids from their mixed-acid fermentation pathways. These compounds have the potential for conversion to biofuels in downstream biological processes. As outlined in Section 4.2.2, anaerobic fungi produce $\mathrm{H}_{2}$ via dark fermentation. Examples of known soluble co-products of fungal $\mathrm{H}_{2}$ production include acetic and formic acids. The formation of these alternative end-products makes it unfeasible for the hydrogenosome metabolic pathway to achieve $100 \%$ efficiency in the conversion of carbohydrate $\mathrm{H}$ atoms to $\mathrm{H}_{2}$ gas. Previously, the maximum theoretical yield of $\mathrm{H}_{2}$ from dark fermentation by organisms coproducing acetic acid has been reported to be 4 mol- $\mathrm{H}_{2}$ mol-hexose ${ }^{-1}$ (Equation (1)) [133].

$$
\mathrm{C}_{6} \mathrm{H}_{12} \mathrm{O}_{6}+2 \mathrm{H}_{2} \mathrm{O} \rightarrow 2 \mathrm{CH}_{3} \mathrm{COOH}+2 \mathrm{CO}_{2}+4 \mathrm{H}_{2}
$$

There is an opportunity for industry to add value to the dark fermentation process by anaerobic fungi via integration of microorganisms which can utilise organic acids for the production of additional biofuel in the form of $\mathrm{CH}_{4}$ or $\mathrm{H}_{2}$ (Figure 4).

\subsubsection{Integration of Dark Fermentation with Biomethane Production}

Methanogenic archaea are capable of converting acetic and formic acids into $\mathrm{CH}_{4}$ via Equations (2) and (3) [161].

$$
\begin{gathered}
4 \mathrm{HCOOH} \rightarrow \mathrm{CH}_{4}+3 \mathrm{CO}_{2}+2 \mathrm{H}_{2} \mathrm{O} \\
\mathrm{CH}_{3} \mathrm{COOH} \rightarrow \mathrm{CH}_{4}+\mathrm{CO}_{2}
\end{gathered}
$$


a

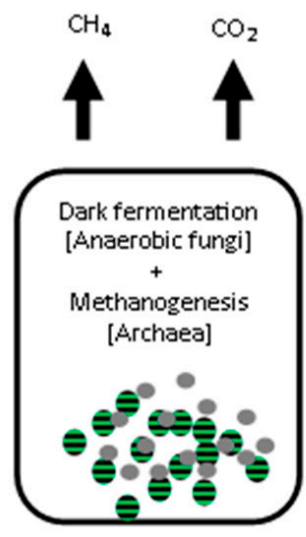

c
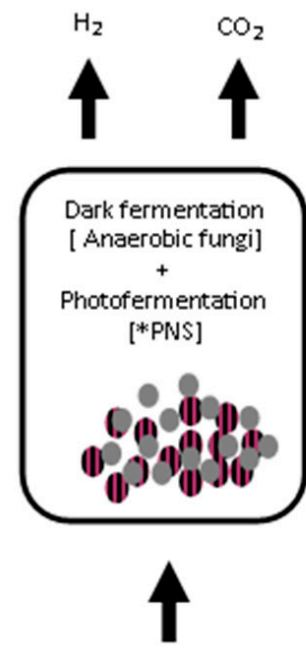

Light

e

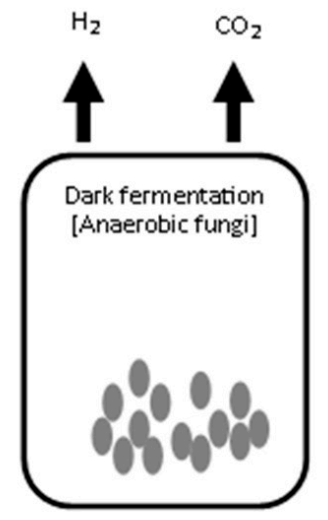

b

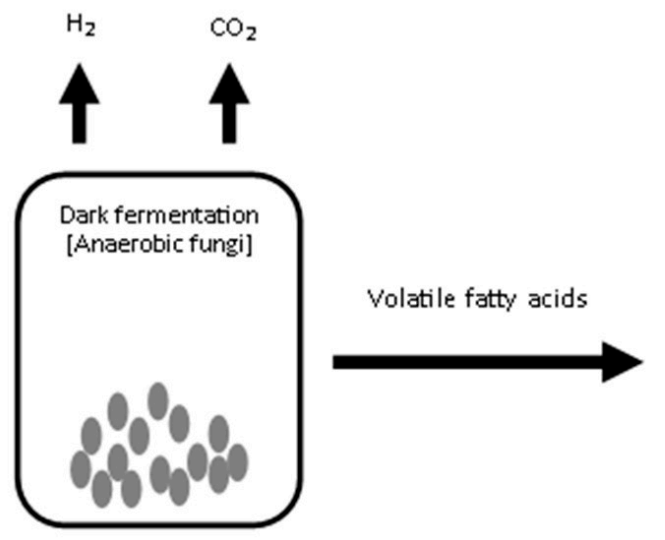

d

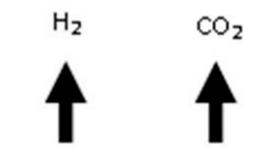

Dark fermentation [Anaerobic fungi]

* Purple norrsulphur bacteria

Volatile fatty acids
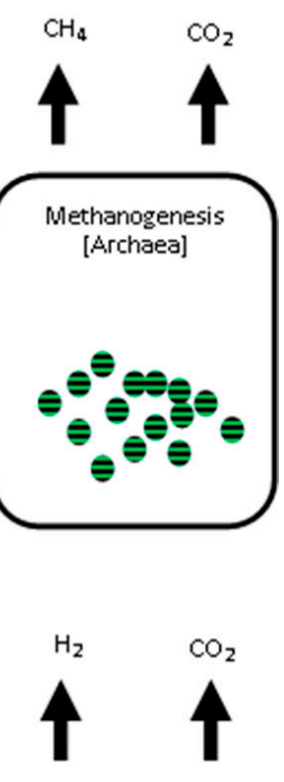

Photofermentation [*PN\$]
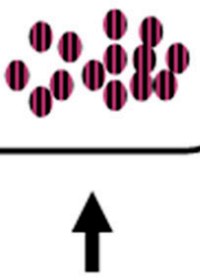

Light

External power input

Volatile fatty acids

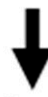
$\mathrm{H}_{2}$

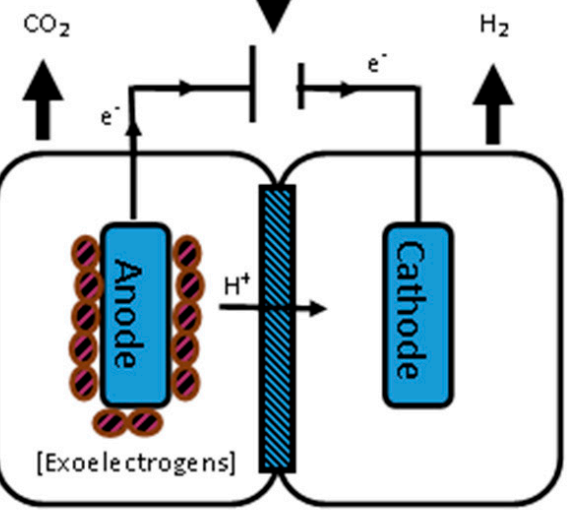

Microbial Electrolysis Cell

Figure 4. A schematic representation of the incorporation of anaerobic fungi into (a) single-stage biomethane production; (b) two-stage dark fermentation and methanogenesis; (c) single-stage dark fermentation and photofermentation; (d) twostage dark fermentation and photofermentation; and (e) two-stage dark fermentation and microbial electrolysis. 
Anaerobic fungal and methanogenesis pathways have the potential for integration as has been reported and industrialised for bacteria-archaea relationships [162]. Methanogenesis of dark fermentation products could be utilised in a single-stage bioreactor containing a mixture of anaerobic fungi and archaea (see, e.g., in $[129,144]$ ) (Figure 4a). Alternatively, a two-stage system could be used in which $\mathrm{H}_{2}$ is obtained from the first stage and $\mathrm{CH}_{4}$ collected from the subsequent second stage (Figure $4 \mathrm{~b}$ ). In the proposed two-stage system, the second stage would be physically separated and optimised for methanogenesis of compounds in the effluent from dark fermentation by anaerobic fungi. A number of conventional, continuously-fed bacterial anaerobic digestion studies have reported higher energy recovery yields of $11-37 \%$ when using two-stage systems in comparison to singlestage operation $[163,164]$. As previously discussed, research investigating co-culture of anaerobic fungi with methanogens strongly indicates that the presence of archaea promotes the activity of the fungus $[5,6,66,138,139,141-145]$. Comparisons of energy yields are necessary between single-stage co-culturing of anaerobic fungi and methanogens to produce solely $\mathrm{CH}_{4}$ or segregation of their growth in a two-stage system to obtain $\mathrm{H}_{2}$ and $\mathrm{CH}_{4}$.

\subsubsection{Integration of Dark Fermentation with Additional Biohydrogen Production}

The soluble organic acids produced during dark fermentation are potentially suitable feed substrates for emerging downstream biological $\mathrm{H}_{2}$ production technologies such as microbial electrolysis cells (MEC) or photofermentation. These systems are attractive because according to stoichiometry they are theoretically capable of converting acetic acid produced from each mole of hexose consumed by the anaerobic fungus into an additional $8 \mathrm{~mol} \mathrm{H}_{2}$ [165]. The combination of dark fermentation followed by either photofermentation or MEC could hypothetically achieve the complete conversion of $\mathrm{H}$ atoms in hexose to $\mathrm{H}_{2}$ fuel. This subsection discussed the concept and technological challenges of integrating dark fermentation by anaerobic fungi with MEC and photofermentation processes.

\section{Photofermentation}

Photofermentation is performed by purple non-sulphur (PNS) bacteria which are able to generate $\mathrm{H}_{2}$ by utilising dark fermentation acids in the presence of light [166]. When this group of bacteria are growing photo-heterotrophically, the production of $\mathrm{H}_{2}$ is catalysed by nitrogenase. PNS bacteria can oxidise organic acids (e.g., acetate) in a tricarboxylic acid cycle and shuttle the released electrons to nitrogenase via NAD/NADH and ferredoxin. The reduction of protons is energetically expensive and the ATP required to drive the nitrogenase reaction is provided by a combination of photosystem I and ATP synthase [167]. Photofermentation should be carried out in the absence of $\mathrm{N}_{2}$ to avoid protonation of $\mathrm{N}$ by nitrogenase to create ammonia at the expense of $\mathrm{H}_{2}$ [168]. The optimal $\mathrm{pH}$ and temperature for photofermentation are considered to be neutral and mesophilic, respectively [169]. Moreover, PNS bacteria are anaerobic or microaerophilic and collectively, culture conditions are similar to those required by anaerobic fungi. Therefore, similar to the suggested configurations of anaerobic fungi and methanogens, PNS bacteria could in principle perform photofermentation of fungal products in a single-stage co-culture or sequentially in a separated second-stage bioreactor (Figure 4c,d).

Integration of bacterial dark fermentation and photofermentation has previously been used to process various carbohydrates including starch [170], glucose [171], cellulose [172] and molasses [173]. It is expected that the knowledge gained from previous bacterial studies will aid the future development of photofermentation systems that include anaerobic fungi. Currently, commercialisation and wide-scale use of PNS photofermentation technology is restricted by the costs associated with high-intensity external lighting requirements and light-permeable bioreactors [169]. There is also the requirement for suitable technology to clarify dark fermentation effluents before photofermentation can occur [174]. Recent developments in the field of microalgal photobioreactors which employ the use of low-cost, low-voltage, high-intensity LED lighting, positioned in situ in the reactor show considerable promise and could be adapted for PNS bacteria and anaerobic fungal co-culture systems. 


\section{Microbial Electrolysis Cells (MEC)}

The first successful use of a MEC to generate $\mathrm{H}_{2}$ was reported by Liu et al. [175] and used acetate as a carbon source. MEC are adaptions of microbial fuel cells (which typically consist of an anaerobic anode electrode chamber containing microbes and an oxygenated cathode electrode chamber). In a MEC, both electrodes are operated under anaerobic conditions and the circuit is supplemented with external power (Figure 4e). Biological oxidation of organic compounds (e.g., acetate and formate [176]) by anaerobic microbial growth at the anode releases protons and electrons. These electrons and protons differ in their routes to the cathode and travel via the electrodes or in solution, respectively. Provision of external power to the electrodes $(>0.2 \mathrm{~V}$ [177]) creates the necessary redox potential for electrons and protons to recombine at the cathode producing $\mathrm{H}_{2}$ gas. Crucially, MEC systems supplied with acetate require approximately 1/10th the external power needed for abiotic $\mathrm{H}_{2}$ production in electrolysis of $\mathrm{H}_{2} \mathrm{O}$ [175]. Since the inception of MEC, advancements have been made to their design and operational parameters [178]. For example, Hou et al. [179] consistently achieved a $\mathrm{H}_{2}$ yield greater than 3 mol- $\mathrm{H}_{2}$ mol-acetate ${ }^{-1}$ throughout 60 days of operation while using a single chamber MEC variation in which methanogenesis was suppressed by UV irradiation. MECs have now been used to generate $\mathrm{H}_{2}$ from a range of bacterial dark fermentation effluents [180-182], paving the way for the future application of this technology to the products of dark fermentation by anaerobic fungi. Challenges faced by MEC scale-up include fouling of electrodes [183], optimisation of electrode surface area to reactor volume [184] and the prevention of methanogenesis in single-chamber reactors [185].

The discussed technologies, capable of converting organic acids from dark fermentation into additional $\mathrm{H}_{2}$, are less mature than those that produce $\mathrm{CH}_{4}$. Nevertheless, in time, the downstream implementation of MEC or photofermentation could provide industrial opportunities that make use of the superior ability of anaerobic fungi to degrade abundantly available lignocellulose for the purpose of producing significant amounts of green $\mathrm{H}_{2}$.

\section{Conclusions}

Despite their biotechnological relevance and their prevalence as a critical component of ruminant biology for recovering resources from plants, anaerobic fungi remain relatively unexplored as platform organisms for lignocellulosic breakdown and biofuel production. Mimicking natural rumen and hind-gut environments in a scalable bioreactor remains a formidable challenge. The development of robust, low energy, heterologous, scalable processes that are able to make use of complex lignocellulose substrates is critical for effective process-scale production of biofuels. Except for $\mathrm{AD}$ reactors, most bioprocessing strategies have been well developed and optimised for aerobic microorganisms with very different growth requirements. Nevertheless, boundless opportunities arise to exploit the enzyme systems and metabolism of anaerobic fungi, whether by producing genes in heterologous platforms, by developing the means to genetically engineer the fungi directly, or by repurposing existing or developing new bioreactor designs. Such work provides an opportunity to potentially produce not only biofuels but platform molecules from one of the most abundant and renewable feedstocks on the planet.

Author Contributions: Conceptualisation, M.R. and M.K.T.; writing-original draft preparation, L.M.G.S., T.A.N., M.R. and M.K.T.; writing-review and editing, J.P.J.C., M.A.O., L.M.G.S., T.A.N., M.R. and M.K.T.; supervision, J.P.J.C., M.A.O., M.R. and M.K.T.; funding acquisition, M.R., M.K.T., M.A.O. and J.P.J.C. All authors have read and agreed to the published version of the manuscript.

Funding: L.M.G. Saye wishes to thank the Department of Biology at The University of York and Harper Adams University for studentship funding. M. Reilly would like to acknowledge EPSRC Innovation Fellowship funding (grant code: EP/S001581/1). M.K. Theodorou wishes to thank Harper Adams University for providing funds to permit mentoring and supervisory support. M.A. O'Malley and T.A. Navaratna are grateful for funding support from the U.S. Department of Energy, Office of 
Science, Office of Biological and Environmental Research under award number DE-SC0020420. J.P.J. Chong is a Royal Society Industry Fellow (IF160022) and would like to acknowledge the support of BBSRC (BB/T000740/1) and the ADCEY project, which is partly funded by the European Regional Development Fund.

Institutional Review Board Statement: Not applicable.

Informed Consent Statement: Not applicable.

Conflicts of Interest: The authors declare no conflict of interest.

\section{References}

1. Yang, B.; Wyman, C.E. Pretreatment: The key to unlocking low-cost cellulosic ethanol. Biofuels Bioprod. Biorefining 2008, 2 , 26-40. [CrossRef]

2. Chen, H.; Liu, J.; Chang, X.; Chen, D.; Xue, Y.; Liu, P.; Lin, H.; Han, S. A review on the pretreatment of lignocellulose for high-value chemicals. Fuel Process. Technol. 2017, 160, 196-206. [CrossRef]

3. Flad, V.; Young, D.; Seppälä, S.; Hooker, C.; Youssef, N.; Podmirseg, S.M.; Nagler, M.; Reilly, M.; Li, Y.; Fliegerová, K.; et al. 17 The Biotechnological Potential of Anaerobic Gut Fungi. In Genetics and Biotechnology; Springer International Publishing: Berlin/Heidelberg, Germany, 2020; pp. 413-437.

4. Solomon, K.V.; Haitjema, C.H.; Henske, J.K.; Gilmore, S.P.; Borges-Rivera, D.; Lipzen, A.; Brewer, H.M.; Purvine, S.O.; Wright, A.T.; Theodorou, M.K.; et al. Early-branching gut fungi possess a large, comprehensive array of biomass-degrading enzymes. Science 2016, 351, 1192-1195. [CrossRef] [PubMed]

5. Bauchop, T.; Mountfort, D.O. Cellulose Fermentation by a Rumen Anaerobic Fungus in Both the Absence and the Presence of Rumen Methanogens. Appl. Environ. Microbiol. 1981, 42, 1103-1110. [CrossRef] [PubMed]

6. Joblin, K.N.; Campbell, G.P.; Richardson, A.J.; Stewart, C.S. Fermentation of barley straw by anaerobic rumen bacteria and fungi in axenic culture and in co-culture with methanogens. Lett. Appl. Microbiol. 1989, 9, 195-197. [CrossRef]

7. Orpin, C.G. Studies on the rumen flagellate Neocallimastix frontalis. J. Gen. Microbiol. 1975, 91, 249-262. [CrossRef]

8. Orpin, C.G. Studies on the rumen flagellate Sphaeromonas communis. J. Gen. Microbiol. 1976, 94, 270-280. [CrossRef]

9. Orpin, C.G. The rumen flagellate Piromonas communis: Its life history and invasion of plant material in the rumen. J. Gen. Microbiol. 1977, 99, 107-117. [CrossRef]

10. Braune, R. Untersuchungen über die im Wiederkäuermagen vorkommenden Protozoen. Arch. Protistenkd. 1913, 32, 111-170.

11. Hsiung, T.-S. A Monograph on the Protozoa of the Large Intestine of the Horse. Master's Thesis, Iowa State University, Ames, IA, USA, 1930.

12. Weissenberg, R. Callimastix cyclopis, ng, n. sp., ein geisseltragendes Protozoon aus dem Serum von Cyclops. Sitz. Ges. Naturfr Freunde 1912, 5, 299-305.

13. Weissenberg, R. The development and affinities of Callimastix cyclopis Weissenberg, a parasitic microorganism from the serum of Cyclops. Proc. Am. Soc. Protozool. 1950, 1, 4-5.

14. Liebentanz, E. Die parasitischen Protozoen des Wiederkäuermayens. Arch. Protistenkd. 1910, 19, 19-80.

15. Vavra, J.; Joyon, L. Étude sur la morphologie, le cycle évolutif et la position systématique de Callimastix cyclopsis Weissenberg 1912. Pro-Tislologica 1966, 2, 15-16.

16. Li, J.; Heath, I.B.; Packer, L. The phylogenetic relationships of the anaerobic chytridiomycetous gut fungi (Neocallimasticaceae) and the Chytridiomycota. II. Cladistic analysis of structural data and description of Neocallimasticales ord.nov. Can. J. Bot. 1993, 71, 393-407. [CrossRef]

17. Hibbett, D.S.; Binder, M.; Bischoff, J.F.; Blackwell, M.; Cannon, P.F.; Eriksson, O.E.; Huhndorf, S.; James, T.; Kirk, P.M.; Lücking, R.; et al. A higher-level phylogenetic classification of the Fungi. Mycol. Res. 2007, 111, 509-547. [CrossRef] [PubMed]

18. Stabel, M.; Hanafy, R.A.; Schweitzer, T.; Greif, M.; Aliyu, H.; Flad, V.; Young, D.; Lebuhn, M.; Elshahed, M.S.; Ochsenreither, K.; et al. Aestipascuomyces dupliciliberans gen. Nov, sp. nov., the first cultured representative of the uncultured SK4 clade from aoudad sheep and alpaca. Microorganisms 2020, 8, 1734. [CrossRef]

19. Gleason, F.H.; Kagami, M.; Lefevre, E.; Sime-Ngando, T. The ecology of chytrids in aquatic ecosystems: Roles in food web dynamics. Fungal Biol. Rev. 2008, 22, 17-25. [CrossRef]

20. Davies, D.R.; Theodorou, M.K.; Lawrence, M.I.G.; Trinci, A.P.J. Distribution of anaerobic fungi in the digestive tract of cattle and their survival in faeces. J. Gen. Microbiol. 1993, 139, 1395-1400. [CrossRef] [PubMed]

21. Davies, D.R.; Theodorou, M.K.; Brooks, A.E.; Trinci, A.P.J. Influence of drying on the survival of anaerobic fungi in rumen digesta and faeces of cattle. FEMS Microbiol. Lett. 1993, 106, 59-63. [CrossRef] [PubMed]

22. James, T.Y.; Kauff, F.; Schoch, C.L.; Matheny, P.B.; Hofstetter, V.; Cox, C.J.; Celio, G.; Gueidan, C.; Fraker, E.; Miadlikowska, J.; et al. Reconstructing the early evolution of Fungi using a six-gene phylogeny. Nature 2006, 443, 818-822. [CrossRef]

23. James, T.Y.; Letcher, P.M.; Longcore, J.E.; Mozley-Standridge, S.E.; Porter, D.; Powell, M.J.; Griffith, G.W.; Vilgalys, R. A molecular phylogeny of the flagellated fungi (Chytridiomycota) and description of a new phylum (Blastocladiomycota). Mycologia 2006, 98, 860-871. [CrossRef] [PubMed] 
24. Wang, Y.; Youssef, N.; Couger, M.; Hanafy, R.; Elshahed, M.; Stajich, J.E. Comparative genomics and divergence time estimation of the anaerobic fungi in herbivorous mammals. bioRxiv 2018, 401869. [CrossRef]

25. Hobson, P.N.; Wallace, R.J.; Bryant, M.P. Microbial ecology and activities in the rumen: Part I. Crit. Rev. Microbiol. 1982, 9, 165-225. [CrossRef] [PubMed]

26. Mambrini, M.; Peyraud, J.L. Retention time of feed particles and liquids in the stomachs and intestines of dairy cows. Direct measurement and calculations based on faecal collection. Reprod. Nutr. Dev. 1997, 37, 427-442. [CrossRef]

27. Bartocci, S.; Amici, A.; Verna, M.; Terramoccia, S.; Martillotti, F. Solid and fluid passage rate in buffalo, cattle and sheep fed diets with different forage to concentrate ratios. Livest. Prod. Sci. 1997, 52, 201-208. [CrossRef]

28. Van Weyenberg, S.; Sales, J.; Janssens, G.P.J. Passage rate of digesta through the equine gastrointestinal tract: A review. Livest. Sci. 2006, 99, 3-12. [CrossRef]

29. Hobson, P.N. Rumen micro-organisms. Prog. Ind. Microbiol. 1971, 9, 41-77. [PubMed]

30. Ulyatt, M.J.; Dellow, D.W.; John, A.; Reid, C.S.W.; Waghorn, G.C. Contribution of chewing during eating and rumination to the clearance of digesta from the rumen reticulum. In Control of Digestion and Metabolism in Ruminants. In Proceedings of the 6th International Symposium on Ruminant Physiology, Banff, AB, Canada, 14-16 September 1984; pp. 498-515.

31. Ulyatt, M.J.; Baldwin, R.L.; Koong, L.J. The basis of nutritive value-A modelling approach. Proc. N. Z. Soc. Anim. Prod. 1976, $36,140-149$.

32. Nishida, A.H.; Ochman, H. Rates of gut microbiome divergence in mammals. Mol. Ecol. 2018, 27, 1884-1897. [CrossRef]

33. Hume, I.D. Optimal digestive strategies in mammalian herbivores. Physiol. Zool. 1989, 62, 1145-1163. [CrossRef]

34. Soest, P.J. Van Nutritional Ecology of the Ruminant, 2nd ed.; Cornell University Press: Ithaca, NY, USA, 1994 ; ISBN 9780801427725.

35. France, J.; Dhanoa, M.S.; Theodorou, M.K.; Lister, S.J.; Davies, D.R.; Isac, D. A model to interpret gas accumulation profiles associated with in vitro degradation of ruminant feeds. J. Theor. Biol. 1993, 163, 99-111. [CrossRef]

36. Peng, X.; Wilken, S.E.; Lankiewicz, T.S.; Gilmore, S.P.; Brown, J.L.; Henske, J.K.; Swift, C.L.; Salamov, A.; Barry, K.; Grigoriev, I.V.; et al. Genomic and functional analyses of fungal and bacterial consortia that enable lignocellulose breakdown in goat gut microbiomes. Nat. Microbiol. 2021, 1-13. [CrossRef]

37. Haitjema, C.H.; Gilmore, S.P.; Henske, J.K.; Solomon, K.V.; De Groot, R.; Kuo, A.; Mondo, S.J.; Salamov, A.A.; LaButti, K.; Zhao, Z.; et al. A parts list for fungal cellulosomes revealed by comparative genomics. Nat. Microbiol. 2017, 2, 17087. [CrossRef]

38. Edwards, J.E.; Kingston-Smith, A.H.; Jimenez, H.R.; Huws, S.A.; Skøt, K.P.; Griffith, G.W.; McEwan, N.R.; Theodorou, M.K. Dynamics of initial colonization of nonconserved perennial ryegrass by anaerobic fungi in the bovine rumen. FEMS Microbiol. Ecol. 2008, 66, 537-545. [CrossRef]

39. Theodorou, M.K.; Gill, M.; King-Spooner, C.; Beever, D.E. Enumeration of anaerobic chytridiomycetes as thallus-forming units: Novel method for quantification of fibrolytic fungal populations from the digestive tract ecosystem. Appl. Environ. Microbiol. 1990, 56, 1073-1078. [CrossRef] [PubMed]

40. Lowe, S.E.; Griffith, G.G.; Milne, A.; Theodorou, M.K.; Trinci, A.P.J. The life cycle and growth kinetics of an anaerobic rumen fungus. J. Gen. Microbiol. 1987, 133, 1815-1827. [CrossRef]

41. Joblin, K.N. Isolation, Enumeration, and Maintenance of Rumen Anaerobic Fungi in Roll Tubes. Appl. Environ. Microbiol. 1981, 42, 1119-1122. [CrossRef] [PubMed]

42. Leedle, J.A.; Bryant, M.P.; Hespell, R.B. Diurnal variations in bacterial numbers and fluid parameters in ruminal contents of animals fed low- or high-forage diets. Appl. Environ. Microbiol. 1982, 44, 402-412. [CrossRef] [PubMed]

43. Theodorou, M.K.; Beever, D.E.; Haines, M.J.; Brooks, A. The effect of a fungal probiotic on intake and performance of early weaned calvesle. Anim. Prod. 1990, 50, 577.

44. Gordon, G.L.R.; Phillips, M.W. The role of anaerobic gut fungi in ruminants. Nutr. Res. Rev. 1998, 11, 133-168. [CrossRef]

45. Gordon, G.L.R.; Phillips, M.W. Removal of anaerobic fungi from the rumen of sheep by chemical treatment and the effect on feed consumption and in vivo fibre digestion. Lett. Appl. Microbiol. 1993, 17, 220-223. [CrossRef]

46. Theodorou, M.K.; Zhu, W.-Y.; Rickers, A.; Nielsen, B.B.; Gull, K.; Trinci, A.P.J. Biochemistry and Ecology of Anaerobic Fungi. In Human and Animal Relationships; Springer: Berlin/Heidelberg, Germany, 1996; pp. 265-295.

47. France, J.; Theodorou, M.K.; Davies, D. Use of zoospore concentrations and life cycle parameters in determining the population of anaerobic fungi in the rumen ecosystem. J. Theor. Biol. 1990, 147, 413-422. [CrossRef]

48. Orpin, C.G. On the induction of zoosporogenesis in the rumen phycomycetes Neocallimastix frontalis, Piromonas communis and Sphaeromonas communis. J. Gen. Microbiol. 1977, 101, 181-189. [CrossRef]

49. Trinci, A.P.J.; Davies, D.R.; Gull, K.; Lawrence, M.I.; Bonde Nielsen, B.; Rickers, A.; Theodorou, M.K. Anaerobic fungi in herbivorous animals. Mycol. Res. 1994, 98, 129-152. [CrossRef]

50. Orpin, C.G.; Bountiff, L. Zoospore chemotaxis in the rumen phycomycete Neocallimastix frontalis. J. Gen. Microbiol. 1978, 104, 113-122. [CrossRef]

51. Orpin, C.G.; Greenwood, Y. The role of haems and related compounds in the nutrition and zoosporogenesis of the rumen chytridiomycete Neocallimastix frontalis H8. J. Gen. Microbiol. 1986, 132, 2179-2185. [CrossRef]

52. Wubah, D.A.; Kim, D.S.H. Chemoattraction of anaerobic ruminal fungi zoospores to selected phenolic acids. Microbiol. Res. 1996, 151, 257-262. [CrossRef]

53. Nielsen, B.B.; Zhu, W.Y.; Trinci, A.P.J.; Theodorou, M.K. Demonstration of zoosporangia of anaerobic fungi on plant residues recovered from faeces of cattle. Mycol. Res. 1995, 99, 471-474. [CrossRef] 
54. Gleason, F.H.; Schmidt, S.K.; Marano, A.V. Can zoosporic true fungi grow or survive in extreme or stressful environments? Extremophiles 2010, 14, 417-425. [CrossRef] [PubMed]

55. Dal Pont, J.P. Process Engineering and Industrial Management; John Wiley \& Sons: Hoboken, NJ, USA, $2013 ;$ ISBN 9781848213265.

56. Lockhart, R.J.; Van Dyke, M.I.; Beadle, I.R.; Humphreys, P.; McCarthy, A.J. Molecular biological detection of anaerobic gut fungi (Neocallimastigales) from landfill sites. Appl. Environ. Microbiol. 2006, 72, 5659-5661. [CrossRef] [PubMed]

57. Dollhofer, V.; Callaghan, T.M.; Griffith, G.W.; Lebuhn, M.; Bauer, J. Presence and transcriptional activity of anaerobic fungi in agricultural biogas plants. Bioresour. Technol. 2017, 235, 131-139. [CrossRef]

58. Young, D.; Dollhofer, V.; Callaghan, T.M.; Reitberger, S.; Lebuhn, M.; Benz, J.P. Isolation, identification and characterization of lignocellulolytic aerobic and anaerobic fungi in one- and two-phase biogas plants. Bioresour. Technol. 2018, 268, 470-479. [CrossRef]

59. Fliegerová, K.; Mrázek, J.; Hoffmann, K.; Zábranská, J.; Voigt, K. Diversity of anaerobic fungi within cow manure determined by ITS1 analysis. Folia Microbiol. 2010, 55, 319-325. [CrossRef]

60. Drake, H.; Ivarsson, M. The role of anaerobic fungi in fundamental biogeochemical cycles in the deep biosphere. Fungal Biol. Rev. 2018, 32, 20-25. [CrossRef]

61. McGranaghan, P.; Davies, J.C.; Griffith, G.W.; Davies, D.R.; Theodorou, M.K. The survival of anaerobic fungi in cattle faeces. FEMS Microbiol. Ecol. 1999, 29, 293-300. [CrossRef]

62. Theodorou, M.K.; King-Spooner, C.; Beever, D.E. Presence or Absence of Anaerobic Fungi in Landfill Refuse; Energy Technology Support Unit, Department of Energy Publications: London, UK, 1989; pp. 1-40.

63. Dollhofer, V.; Dandikas, V.; Dorn-In, S.; Bauer, C.; Lebuhn, M.; Bauer, J. Accelerated biogas production from lignocellulosic biomass after pre-treatment with Neocallimastix frontalis. Bioresour. Technol. 2018, 264, 219-227. [CrossRef] [PubMed]

64. Ferraro, A.; Dottorini, G.; Massini, G.; Mazzurco Miritana, V.; Signorini, A.; Lembo, G.; Fabbricino, M. Combined bioaugmentation with anaerobic ruminal fungi and fermentative bacteria to enhance biogas production from wheat straw and mushroom spent straw. Bioresour. Technol. 2018, 260, 364-373. [CrossRef]

65. Vinzelj, J.; Joshi, A.; Insam, H.; Podmirseg, S.M. Employing anaerobic fungi in biogas production: Challenges \& opportunities. Bioresour. Technol. 2020, 300, 122687.

66. Teunissen, M.J.; Kets, E.P.W.; Op den Camp, H.J.M.; Huis in't Veld, J.H.J.; Vogels, G.D. Effect of coculture of anaerobic fungi isolated from ruminants and non-ruminants with methanogenic bacteria on cellulolytic and xylanolytic enzyme activities. Arch. Microbiol. 1992, 157, 176-182. [CrossRef] [PubMed]

67. Gilmore, S.P.; Lankiewicz, T.S.; Wilken, S.E.; Brown, J.L.; Sexton, J.A.; Henske, J.K.; Theodorou, M.K.; Valentine, D.L.; O’Malley, M.A. Top-Down Enrichment Guides in Formation of Synthetic Microbial Consortia for Biomass Degradation. ACS Synth. Biol. 2019, 8, 2174-2185. [CrossRef] [PubMed]

68. Wubah, D.A.; Fuller, M.S.; Akin, D.E. Resistant Body Formation in Neocallimastix Sp., an Anaerobic Fungus from the Rumen of a Cow. Mycologia 1991, 83, 40-47. [CrossRef]

69. Hungate, R.E. The Rumen Bacteria. In Rumen and Its Microbes; Elsevier: Amsterdam, The Netherlands, 1966; pp. 8-90.

70. Bryant, M.P. Commentary on the Hungate technique for culture of anaerobic bacteria. Am. J. Clin. Nutr. 1972, 25, 1324-1328. [CrossRef]

71. Hungate, R.E.; Macy, J. The roll-tube method for cultivation of strict anaerobes. Bull. Ecol. Res. Comm. 1973, 17, 123-126.

72. Miller, T.L.; Wolin, M.J. A Serum Bottle Modification of the Hungate Technique for Cultivating Obligate Anaerobes. Appl. Microbiol. 1974, 27, 985-987. [CrossRef] [PubMed]

73. Theodorou, M.K.; Davies, D.R.; Nielsen, B.B.; Lawrence, M.I.G.; Trinci, A.P.J. Determination of growth of anaerobic fungi on soluble and cellulosic substrates using a pressure transducer. Microbiology 1995, 141, 671-678. [CrossRef]

74. Wilken, S.E.; Monk, J.M.; Leggieri, P.A.; Lawson, C.A.; Lankiewicz, T.S.; Seppälä, S.; Daum, C.; Jenkins, J.; Lipzen, A.; Mondo, S.J.; et al. Experimentally validated reconstruction and analysis of a genome-scale metabolic model of an anaerobic Neocallimastigomycota fungus. mSystems 2021, in press.

75. Zhu, W.Y.; Theodorou, M.K.; Longland, A.C.; Nielsen, B.B.; Dijkstra, J.; Trinci, A.P.J. Growth and survival of anaerobic fungi in batch and continuous-flow cultures. Anaerobe 1996, 2, 29-37. [CrossRef]

76. Zhu, W.Y.; Theodorou, M.K.; Nielsen, B.B.; Trinci, A.P.J. Dilution rate increases production of plant cell-wall degrading enzymes by anaerobic fungi in continuous-flow culture. Anaerobe 1997, 3, 49-59. [CrossRef] [PubMed]

77. Lonsane, B.K.; Ghildyal, N.P.; Budiatman, S.; Ramakrishna, S. V Engineering aspects of solid state fermentation. Enzyme Microb. Technol. 1985, 7, 258-265. [CrossRef]

78. Soccol, C.R.; da Costa, E.S.F.; Letti, L.A.J.; Karp, S.G.; Woiciechowski, A.L.; de Vandenberghe, L.P.S. Recent developments and innovations in solid state fermentation. Biotechnol. Res. Innov. 2017, 1, 52-71. [CrossRef]

79. Moo-Young, A.R.; Tengerdy, R.P.; Moreira, M. Principles of solid-substrate fermentation. Filam. Fungi 1983, 4, 117-144.

80. Tengerdy, R.P. Solid substrate fermentation. Trends Biotechnol. 1985, 3, 96-99. [CrossRef]

81. Tengerdy, R.P.; Szakacs, G. Bioconversion of lignocellulose in solid substrate fermentation. Biochem. Eng. J. 2003, 13, 169-179. [CrossRef]

82. Duff, S.J.B.; Murray, W.D. Bioconversion of forest products industry waste cellulosics to fuel ethanol: A review. Bioresour. Technol. 1996, 55, 1-33. [CrossRef]

83. Himmel, M.E.; Ruth, M.F.; Wyman, C.E. Cellulase for commodity products from cellulosic biomass. Curr. Opin. Biotechnol. 1999, 10, 358-364. [CrossRef] 
84. Rayner, A.D.M.; Boddy, L. Fungal Communities in the Decay of Wood. In Advances in Microbial Ecology; Springer: Boston, MA, USA, 1988; pp. 115-166.

85. Kim, S.W.; Kang, S.W.; Lee, J.S. Cellulase and xylanase production by Aspergillus niger KKS in various bioreactors. Bioresour. Technol. 1997, 59, 63-67. [CrossRef]

86. Ishida, H.; Hata, Y.; Ichikawa, E.; Kawato, A.; Suginami, K.; Imayasu, S. Regulation of the glucoamylase-encoding gene (glaB), expressed in solid- state culture (koji) of Aspergillus oryzae. J. Ferment. Bioeng. 1998, 86, 301-307. [CrossRef]

87. Arora, S.; Rani, R.; Ghosh, S. Bioreactors in solid state fermentation technology: Design, applications and engineering aspects. J. Biotechnol. 2018, 269, 16-34. [CrossRef]

88. Farinas, C.S. Developments in solid-state fermentation for the production of biomass-degrading enzymes for the bioenergy sector. Renew. Sustain. Energy Rev. 2015, 52, 179-188. [CrossRef]

89. Youssef, N.H.; Couger, M.B.; Struchtemeyer, C.G.; Liggenstoffer, A.S.; Prade, R.A.; Najar, F.Z.; Atiyeh, H.K.; Wilkins, M.R.; Elshahed, M.S. The genome of the anaerobic fungus orpinomyces sp. strain cla reveals the unique evolutionary history of a remarkable plant biomass degrader. Appl. Environ. Microbiol. 2013. [CrossRef] [PubMed]

90. Gilmore, S.P.; Lillington, S.P.; Haitjema, C.H.; de Groot, R.; O’Malley, M.A. Designing chimeric enzymes inspired by fungal cellulosomes. Synth. Syst. Biotechnol. 2020, 5, 23-32. [CrossRef]

91. Gilmore, S.P.; Henske, J.K.; O’Malley, M.A. Driving biomass breakdown through engineered cellulosomes. Bioengineered 2015, 6, 204-208. [CrossRef]

92. Haitjema, C.H.; Solomon, K.V.; Henske, J.K.; Theodorou, M.K.; O’Malley, M.A. Anaerobic gut fungi: Advances in isolation, culture, and cellulolytic enzyme discovery for biofuel production. Biotechnol. Bioeng. 2014. [CrossRef] [PubMed]

93. Podolsky, I.A.; Seppälä, S.; Lankiewicz, T.S.; Brown, J.L.; Swift, C.L.; O’Malley, M.A. Harnessing Nature's Anaerobes for Biotechnology and Bioprocessing. Annu. Rev. Chem. Biomol. Eng. 2019, 10, 105-128. [CrossRef]

94. Wilken, S.E.; Swift, C.L.; Podolsky, I.A.; Lankiewicz, T.S.; Seppälä, S.; O’Malley, M.A. Linking “omics” to function unlocks the biotech potential of non-model fungi. Curr. Opin. Syst. Biol. 2019, 14, 9-17. [CrossRef]

95. Durand, R.; Rascle, C.; Fischer, M.; Fèvre, M. Transient expression of the $\beta$-glucuronidase gene after biolistic transformation of the anaerobic fungus Neocallimastix frontalis. Curr. Genet. 1997, 31, 158-161. [CrossRef]

96. Henske, J.K.; Wilken, S.E.; Solomon, K.V.; Smallwood, C.R.; Shutthanandan, V.; Evans, J.E.; Theodorou, M.K.; O’Malley, M.A. Metabolic characterization of anaerobic fungi provides a path forward for bioprocessing of crude lignocellulose. Biotechnol. Bioeng. 2018, 115, 874-884. [CrossRef] [PubMed]

97. Weld, R.J.; Plummer, K.M.; Carpenter, M.A.; Ridgway, H.J. Approaches to functional genomics in filamentous fungi. Cell Res. 2006, 16, 31-44. [CrossRef] [PubMed]

98. Teunissen, M.J.; Op Den Camp, H.J.M.; Orpin, C.G.; Huis, J.H.; Vogels, G.D. Comparison of growth characteristics of anaerobic fungi isolated from ruminant and non-ruminant herbivores during cultivation in a defined medium. J. Gen. Microbiol. 1991, 137, 1401-1408. [CrossRef]

99. Gleason, F.H.; Lilje, O. Structure and function of fungal zoospores: Ecological implications. Fungal Ecol. 2009, 2, 53-59. [CrossRef]

100. Calkins, S.; Elledge, N.C.; Hanafy, R.A.; Elshahed, M.S.; Youssef, N. A fast and reliable procedure for spore collection from anaerobic fungi: Application for RNA uptake and long-term storage of isolates. J. Microbiol. Methods 2016, 127, 206-213. [CrossRef]

101. Calkins, S.S.; Elledge, N.C.; Mueller, K.E.; Marek, S.M.; Couger, M.B.; Elshahed, M.S.; Youssef, N.H. Development of an RNA interference (RNAi) gene knockdown protocol in the anaerobic gut fungus Pecoramyces ruminantium strain C1A. PeerJ 2018, 6, e4276. [CrossRef]

102. Mello, C.C.; Conte, D. Revealing the world of RNA interference. Nature 2004, 431, 338-342. [CrossRef] [PubMed]

103. Swafford, A.J.M.; Hussey, S.P.; Fritz-Laylin, L.K. High-efficiency electroporation of chytrid fungi. Sci. Rep. 2020, 10, 15145. [CrossRef]

104. Yin, H.; Kanasty, R.L.; Eltoukhy, A.A.; Vegas, A.J.; Dorkin, J.R.; Anderson, D.G. Non-viral vectors for gene-based therapy. Nat. Rev. Genet. 2014, 15, 541-555. [CrossRef] [PubMed]

105. Lowe, S.E.; Theodorou, M.K.; Trinci, A.P.J. Growth and fermentation of an anaerobic rumen fungus on various carbon sources and effect of temperature on development. Appl. Environ. Microbiol. 1987, 53, 1210-1215. [CrossRef]

106. Jin, X.; Xia, L. Heterologous expression of an endo- $\beta-1,4-$ glucanase gene from the anaerobic fungus Orpinomyces PC-2 in Trichoderma reesei. World J. Microbiol. Biotechnol. 2011, 27, 2913-2920. [CrossRef]

107. Wilken, S.E.; Seppälä, S.; Lankiewicz, T.S.; Saxena, M.; Henske, J.K.; Salamov, A.A.; Grigoriev, I.V.; O'Malley, M.A. Genomic and proteomic biases inform metabolic engineering strategies for anaerobic fungi. Metab. Eng. Commun. 2020, 10 , e00107. [CrossRef] [PubMed]

108. Seppälä, S.; Yoo, J.I.; Yur, D.; O’Malley, M.A. Heterologous transporters from anaerobic fungi bolster fluoride tolerance in Saccharomyces cerevisiae. Metab. Eng. Commun. 2019, 9, e00091. [CrossRef]

109. O'Malley, M.A.; Theodorou, M.K.; Kaiser, C.A. Evaluating expression and catalytic activity of anaerobic fungal fibrolytic enzymes native topiromyces sp E2 inSaccharomyces cerevisiae. Environ. Prog. Sustain. Energy 2012, 31, 37-46. [CrossRef]

110. Hooker, C.A.; Lee, K.Z.; Solomon, K. V Leveraging anaerobic fungi for biotechnology. Curr. Opin. Biotechnol. 2019, 59, 103-110. [CrossRef] [PubMed]

111. Ali, S.S.; Nugent, B.; Mullins, E.; Doohan, F.M. Fungal-mediated consolidated bioprocessing: The potential of Fusarium oxysporum for the lignocellulosic ethanol industry. AMB Express 2016, 6, 13. [CrossRef] [PubMed] 
112. Zabed, H.M.; Akter, S.; Yun, J.; Zhang, G.; Awad, F.N.; Qi, X.; Sahu, J.N. Recent advances in biological pretreatment of microalgae and lignocellulosic biomass for biofuel production. Renew. Sustain. Energy Rev. 2019, 105, 105-128. [CrossRef]

113. Zhang, X.; Yu, H.; Huang, H.; Liu, Y. Evaluation of biological pretreatment with white rot fungi for the enzymatic hydrolysis of bamboo culms. Int. Biodeterior. Biodegrad. 2007, 60, 159-164. [CrossRef]

114. López-Abelairas, M.; Álvarez Pallín, M.; Salvachúa, D.; Lú-Chau, T.; Martínez, M.J.; Lema, J.M. Optimisation of the biological pretreatment of wheat straw with white-rot fungi for ethanol production. Bioprocess Biosyst. Eng. 2013, 36, 1251-1260. [CrossRef] [PubMed]

115. Hatakka, A.I. Pretreatment of wheat straw by white-rot fungi for enzymic saccharification of cellulose. Eur. J. Appl. Microbiol. Biotechnol. 1983, 18, 350-357. [CrossRef]

116. Lalak, J.; Kasprzycka, A.; Martyniak, D.; Tys, J. Effect of biological pretreatment of Agropyron elongatum "BAMAR" on biogas production by anaerobic digestion. Bioresour. Technol. 2016, 200, 194-200. [CrossRef]

117. Morrison, J.M.; Elshahed, M.S.; Youssef, N.H. Defined enzyme cocktail from the anaerobic fungus Orpinomyces sp. strain C1A effectively releases sugars from pretreated corn stover and switchgrass. Sci. Rep. 2016, 6, 29217. [CrossRef]

118. Ranganathan, A.; Smith, O.P.; Youssef, N.H.; Struchtemeyer, C.G.; Atiyeh, H.K.; Elshahed, M.S. Utilizing Anaerobic Fungi for Two-stage Sugar Extraction and Biofuel Production from Lignocellulosic Biomass. Front. Microbiol. 2017, 8, 635. [CrossRef]

119. Kamra, D.; Singh, B. Anaerobic Gut Fungi. In Developments in Fungal Biology and Applied Mycology; Springer: Singapore, 2017; pp. 125-134. ISBN 978-981-10-4767-1.

120. Dollhofer, V.; Podmirseg, S.M.; Callaghan, T.M.; Griffith, G.W.; Fliegerová, K. Anaerobic Fungi and Their Potential for Biogas Production. Adv. Biochem. Eng. Biotechnol. 2015, 151, 41-61. [CrossRef]

121. Sharma, H.K.; Xu, C.; Qin, W. Biological Pretreatment of Lignocellulosic Biomass for Biofuels and Bioproducts: An Overview. Waste Biomass Valorization 2019, 10, 235-251. [CrossRef]

122. Henske, J.K.; Gilmore, S.P.; Haitjema, C.H.; Solomon, K.V.; O’Malley, M.A. Biomass-degrading enzymes are catabolite repressed in anaerobic gut fungi. AIChE J. 2018, 64, 4263-4270. [CrossRef]

123. Solomon, K.V.; Henske, J.K.; Gilmore, S.P.; Lipzen, A.; Grigoriev, I.V.; Thompson, D.; O’Malley, M.A. Catabolic repression in early-diverging anaerobic fungi is partially mediated by natural antisense transcripts. Fungal Genet. Biol. 2018, 121, 1-9. [CrossRef] [PubMed]

124. Teunissen, M.J.; DE Kort, G.V.M.; Op Den Camp, H.J.M.; Tveld, J.H.H.I. Production of cellulolytic and xylanolytic enzymes during growth of the anaerobic fungus Piromyces sp. on different substrates. Microbiology 1992, 138, 1657-1664. [CrossRef] [PubMed]

125. Xu, Q.; Singh, A.; Himmel, M.E. Perspectives and new directions for the production of bioethanol using consolidated bioprocessing of lignocellulose. Curr. Opin. Biotechnol. 2009, 20, 364-371. [CrossRef] [PubMed]

126. Srinivasan, K.; Murakami, M.; Nakashimada, Y.; Nishio, N. Efficient production of cellulolytic and xylanolytic enzymes by the rumen anaerobic fungus, Neocallimastix frontalis, in a repeated batch culture. J. Biosci. Bioeng. 2001, 91, 153-158. [CrossRef]

127. Stevenson, D.M.; Weimer, P.J. Isolation and characterization of a Trichoderma strain capable of fermenting cellulose to ethanol. Appl. Microbiol. Biotechnol. 2002, 59, 721-726. [CrossRef]

128. Ali, S.S.; Nugent, B.; Mullins, E.; Doohan, F.M. Insights from the fungus Fusarium oxysporum point to high affinity glucose transporters as targets for enhancing ethanol production from lignocellulose. PLoS ONE 2013, 8, e54701. [CrossRef]

129. Li, Y.; Jin, W.; Mu, C.; Cheng, Y.; Zhu, W. Indigenously associated methanogens intensified the metabolism in hydrogenosomes of anaerobic fungi with xylose as substrate. J. Basic Microbiol. 2017, 57, 933-940. [CrossRef]

130. Nakashimada, Y.; Srinivasan, K.; Murakami, M.; Nishio, N. Direct conversion of cellulose to methane by anaerobic fungus Neocallimastix frontalis and defined methanogens. Biotechnol. Lett. 2000, 22, 223-227. [CrossRef]

131. Dincer, I.; Acar, C. Review and evaluation of hydrogen production methods for better sustainability. Int. J. Hydrog. Energy 2015, 40, 11094-11111. [CrossRef]

132. IEA. The Future of Hydrogen; IEA: Paris, France, 2019.

133. Hawkes, F.R.; Hussy, I.; Kyazze, G.; Dinsdale, R.; Hawkes, D.L. Continuous dark fermentative hydrogen production by mesophilic microflora: Principles and progress. Int. J. Hydrog. Energy 2007, 32, 172-184. [CrossRef]

134. Ohta, S.; Miyamoto, K.; Miura, Y. Hydrogen Evolution as a Consumption Mode of Reducing Equivalents in Green Algal Fermentation. Plant Physiol. 1987, 83, 1022-1026. [CrossRef] [PubMed]

135. Hackstein, J.H.P.; Baker, S.E.; van Hellemond, J.J.; Tielens, A.G.M. Hydrogenosomes of Anaerobic Fungi: An Alternative Way to Adapt to Anaerobic Environments BT-Hydrogenosomes and Mitosomes: Mitochondria of Anaerobic Eukaryotes. In Hydrogenosomes and Mitosomes: Mitochondria of Anaerobic Eukaryotes; Tachezy, J., Ed.; Springer International Publishing: Cham, Switzerland, 2019; pp. 159-175. ISBN 978-3-030-17941-0.

136. Van Niel, E.W.J.; Claassen, P.A.M.; Stams, A.J.M. Substrate and product inhibition of hydrogen production by the extreme thermophile, Caldicellulosiruptor saccharolyticus. Biotechnol. Bioeng. 2003, 81, 255-262. [CrossRef] [PubMed]

137. Hungate, R.E.; Smith, W.; Bauchop, T.; Yu, I.; Rabinowitz, J.C. Formate as an intermediate in the bovine rumen fermentation. J. Bacteriol. 1970, 102, 389-397. [CrossRef] [PubMed]

138. Li, Y.; Jin, W.; Cheng, Y.; Zhu, W. Effect of the Associated Methanogen Methanobrevibacter thaueri on the Dynamic Profile of End and Intermediate Metabolites of Anaerobic Fungus Piromyces sp. F1. Curr. Microbiol. 2016, 73, 434-441. [CrossRef] 
139. Mountfort, D.O.; Asher, R.A.; Bauchop, T. Fermentation of Cellulose to Methane and Carbon Dioxide by a Rumen Anaerobic Fungus in a Triculture with Methanobrevibacter sp. Strain RA1 and Methanosarcina barkeri. Appl. Environ. Microbiol. 1982, 44, 128-134. [CrossRef]

140. Wood, T.M.; Wilson, C.A.; McCrae, S.I.; Joblin, K.N. A highly active extracellular cellulase from the anaerobic rumen fungus Neocallimastix frontalis. FEMS Microbiol. Lett. 1986, 34, 37-40. [CrossRef]

141. Joblin, K.N.; Naylor, G.E.; Williams, A.G. Effect of Methanobrevibacter smithii on Xylanolytic Activity of Anaerobic Ruminal Fungi. Appl. Environ. Microbiol. 1990, 56, 2287-2295. [CrossRef]

142. Cheng, Y.F.; Edwards, J.E.; Allison, G.G.; Zhu, W.-Y.; Theodorou, M.K. Diversity and activity of enriched ruminal cultures of anaerobic fungi and methanogens grown together on lignocellulose in consecutive batch culture. Bioresour. Technol. 2009, 100, 4821-4828. [CrossRef]

143. Marvin-Sikkema, F.D.; Richardson, A.J.; Stewart, C.S.; Gottschal, J.C.; Prins, R.A. Influence of hydrogen-consuming bacteria on cellulose degradation by anaerobic fungi. Appl. Environ. Microbiol. 1990, 56, 3793-3797. [CrossRef]

144. Swift, C.L.; Brown, J.L.; Seppälä, S.; O’Malley, M.A. Co-cultivation of the anaerobic fungus Anaeromyces robustus with Methanobacterium bryantii enhances transcription of carbohydrate active enzymes. J. Ind. Microbiol. Biotechnol. 2019, 46, 1427-1433. [CrossRef]

145. Joblin, K.N.; Williams, A.G. Effect of cocultivation of ruminal chytrid fungi with Methanobrevibacter smithii on lucerne stem degradation and extracellular fungal enzyme activities. Lett. Appl. Microbiol. 1991, 12, 121-124. [CrossRef]

146. Ahring, B.K.; Westermann, P. Product inhibition of butyrate metabolism by acetate and hydrogen in a thermophilic coculture. Appl. Environ. Microbiol. 1988, 54, 2393-2397. [CrossRef]

147. Cazier, E.A.; Trably, E.; Steyer, J.P.; Escudie, R. Biomass hydrolysis inhibition at high hydrogen partial pressure in solid-state anaerobic digestion. Bioresour. Technol. 2015, 190, 106-113. [CrossRef] [PubMed]

148. Mah, R.A.; Kuenen, J.G.; Quayle, J.R.; Quayle, J.R.; Bull, A.T. Methanogenesis and methanogenic partnerships. Philos. Trans. R. Soc. Lond. B Biol. Sci. 1982, 297, 599-616. [CrossRef]

149. Joblin, K.N.; Naylor, G.E. Fermentation of woods by rumen anaerobic fungi. FEMS Microbiol. Lett. 1989, 65, 119-122. [CrossRef]

150. Webb, J.; Theodorou, M.K. Neocallimastix hurleyensis sp.nov., an anaerobic fungus from the ovine rumen. Can. J. Bot. 1991, 69, 1220-1224. [CrossRef]

151. Brookman, J.L.; Mennim, G.; Trinci, A.P.J.; Theodorou, M.K.; Tuckwell, D.S. Identification and characterization of anaerobic gut fungi using molecular methodologies based on ribosomal ITS1 and 18S rRNAThe GenBank accession numbers for the sequences determined in this work are given in Methods. Microbiology 2000, 146, 393-403. [CrossRef]

152. Niño-Navarro, C.; Chairez, I.; Torres-Bustillos, L.; Ramírez-Muñoz, J.; Salgado-Manjarrez, E.; Garcia-Peña, E.I. Effects of fluid dynamics on enhanced biohydrogen production in a pilot stirred tank reactor: CFD simulation and experimental studies. Int. J. Hydrog. Energy 2016, 41, 14630-14640. [CrossRef]

153. Mizuno, O.; Dinsdale, R.; Hawkes, F.R.; Hawkes, D.L.; Noike, T. Enhancement of hydrogen production from glucose by nitrogen gas sparging. Bioresour. Technol. 2000, 73, 59-65. [CrossRef]

154. Cho, S.-K.; Jeong, M.-W.; Choi, Y.-K.; Shin, J.; Shin, S.G. Effects of low-strength ultrasonication on dark fermentative hydrogen production: Start-up performance and microbial community analysis. Appl. Energy 2018, 219, 34-41. [CrossRef]

155. Ramírez-Morales, J.E.; Tapia-Venegas, E.; Campos, J.L.; Ruiz-Filippi, G. Operational behavior of a hydrogen extractive membrane bioreactor (HEMB) during mixed culture acidogenic fermentation. Int. J. Hydrog. Energy 2019, 44, 25565-25574. [CrossRef]

156. Kisielewska, M.; Dębowski, M.; Zieliński, M. Improvement of biohydrogen production using a reduced pressure fermentation. Bioprocess Biosyst. Eng. 2015, 38, 1925-1933. [CrossRef] [PubMed]

157. Massanet-Nicolau, J.; Jones, R.J.; Guwy, A.; Dinsdale, R.; Premier, G.; Mulder, M.J.J. Maximising biohydrogen yields via continuous electrochemical hydrogen removal and carbon dioxide scrubbing. Bioresour. Technol. 2016, 218, 512-517. [CrossRef] [PubMed]

158. Kim, D.-H.; Han, S.-K.; Kim, S.-H.; Shin, H.-S. Effect of gas sparging on continuous fermentative hydrogen production. Int. J. Hydrog. Energy 2006, 31, 2158-2169. [CrossRef]

159. Saady, N.M.C. Homoacetogenesis during hydrogen production by mixed cultures dark fermentation: Unresolved challenge. Int. J. Hydrog. Energy 2013, 38, 13172-13191. [CrossRef]

160. Reilly, M.; Dinsdale, R.; Guwy, A. Mesophilic biohydrogen production from calcium hydroxide treated wheat straw. Int. J. Hydrog. Energy 2014, 39, 16891-16901. [CrossRef]

161. Pan, X.; Angelidaki, I.; Alvarado-Morales, M.; Liu, H.; Liu, Y.; Huang, X.; Zhu, G. Methane production from formate, acetate and H2/CO2; focusing on kinetics and microbial characterization. Bioresour. Technol. 2016, 218, 796-806. [CrossRef] [PubMed]

162. Ali, N.; Gong, H.; Liu, X.; Giwa, A.S.; Wang, K. Evaluation of bacterial association in methane generation pathways of an anaerobic digesting sludge via metagenomic sequencing. Arch. Microbiol. 2020, 202, 31-41. [CrossRef]

163. Luo, G.; Xie, L.; Zhou, Q.; Angelidaki, I. Enhancement of bioenergy production from organic wastes by two-stage anaerobic hydrogen and methane production process. Bioresour. Technol. 2011, 102, 8700-8706. [CrossRef]

164. Massanet-Nicolau, J.; Dinsdale, R.; Guwy, A.; Shipley, G. Use of real time gas production data for more accurate comparison of continuous single-stage and two-stage fermentation. Bioresour. Technol. 2013, 129, 561-567. [CrossRef]

165. Guwy, A.J.; Dinsdale, R.M.; Kim, J.R.; Massanet-Nicolau, J.; Premier, G. Fermentative biohydrogen production systems integration. Bioresour. Technol. 2011, 102, 8534-8542. [CrossRef] [PubMed]

166. Gest, H.; Kamen, M.D. Photoproduction of molecular hydrogen by Rhodospirillum rubrum. Science 1949, 109, 558 LP-559. [CrossRef] 
167. Akhlaghi, N.; Najafpour-Darzi, G. A comprehensive review on biological hydrogen production. Int. J. Hydrog. Energy 2020, 45, 22492-22512. [CrossRef]

168. McKinlay, J.B.; Harwood, C.S. Photobiological production of hydrogen gas as a biofuel. Curr. Opin. Biotechnol. 2010, 21, 244-251. [CrossRef]

169. Hassan, A.H.S.; Mietzel, T.; Brunstermann, R.; Schmuck, S.; Schoth, J.; Küppers, M.; Widmann, R. Fermentative hydrogen production from low-value substrates. World J. Microbiol. Biotechnol. 2018, 34, 176. [CrossRef] [PubMed]

170. Laurinavichene, T.V.; Belokopytov, B.F.; Laurinavichius, K.S.; Khusnutdinova, A.N.; Seibert, M.; Tsygankov, A.A. Towards the integration of dark- and photo-fermentative waste treatment. 4. Repeated batch sequential dark- and photofermentation using starch as substrate. Int. J. Hydrog. Energy 2012, 37, 8800-8810. [CrossRef]

171. Nath, K.; Kumar, A.; Das, D. Hydrogen production by Rhodobacter sphaeroides strain O.U.001 using spent media of Enterobacter cloacae strain DM11. Appl. Microbiol. Biotechnol. 2005, 68, 533-541. [CrossRef] [PubMed]

172. Odom, J.M.; Wall, J.D. Photoproduction of h(2) from cellulose by an anaerobic bacterial coculture. Appl. Environ. Microbiol. 1983, 45, 1300-1305. [CrossRef]

173. Özgür, E.; Mars, A.E.; Peksel, B.; Louwerse, A.; Yücel, M.; Gündüz, U.; Claassen, P.A.M.; Eroğlu, İ. Biohydrogen production from beet molasses by sequential dark and photofermentation. Int. J. Hydrog. Energy 2010, 35, 511-517. [CrossRef]

174. Argun, H.; Kargi, F.; Kapdan, I.K. Light fermentation of dark fermentation effluent for bio-hydrogen production by different Rhodobacter species at different initial volatile fatty acid (VFA) concentrations. Int. J. Hydrog. Energy 2008, 33, 7405-7412. [CrossRef]

175. Liu, H.; Grot, S.; Logan, B.E. Electrochemically Assisted Microbial Production of Hydrogen from Acetate. Environ. Sci. Technol. 2005, 39, 4317-4320. [CrossRef] [PubMed]

176. Kadier, A.; Simayi, Y.; Kalil, M.S.; Abdeshahian, P.; Hamid, A.A. A review of the substrates used in microbial electrolysis cells (MECs) for producing sustainable and clean hydrogen gas. Renew. Energy 2014, 71, 466-472. [CrossRef]

177. Cheng, S.; Logan, B.E. Sustainable and efficient biohydrogen production via electrohydrogenesis. Proc. Natl. Acad. Sci. USA 2007, 104, 18871-18873. [CrossRef] [PubMed]

178. Yang, E.; Omar Mohamed, H.; Park, S.-G.; Obaid, M.; Al-Qaradawi, S.Y.; Castaño, P.; Chon, K.; Chae, K.-J. A review on selfsustainable microbial electrolysis cells for electro-biohydrogen production via coupling with carbon-neutral renewable energy technologies. Bioresour. Technol. 2021, 320, 124363. [CrossRef] [PubMed]

179. Hou, Y.; Luo, H.; Liu, G.; Zhang, R.; Li, J.; Fu, S. Improved Hydrogen Production in the Microbial Electrolysis Cell by Inhibiting Methanogenesis Using Ultraviolet Irradiation. Environ. Sci. Technol. 2014, 48, 10482-10488. [CrossRef] [PubMed]

180. Lalaurette, E.; Thammannagowda, S.; Mohagheghi, A.; Maness, P.-C.; Logan, B.E. Hydrogen production from cellulose in a two-stage process combining fermentation and electrohydrogenesis. Int. J. Hydrog. Energy 2009, 34, 6201-6210. [CrossRef]

181. Li, X.-H.; Liang, D.-W.; Bai, Y.-X.; Fan, Y.-T.; Hou, H.-W. Enhanced H2 production from corn stalk by integrating dark fermentation and single chamber microbial electrolysis cells with double anode arrangement. Int. J. Hydrog. Energy 2014, 39, 8977-8982. [CrossRef]

182. Lu, L.; Ren, N.; Xing, D.; Logan, B.E. Hydrogen production with effluent from an ethanol-H2-coproducing fermentation reactor using a single-chamber microbial electrolysis cell. Biosens. Bioelectron. 2009, 24, 3055-3060. [CrossRef]

183. Werner, C.M.; Katuri, K.P.; Hari, A.R.; Chen, W.; Lai, Z.; Logan, B.E.; Amy, G.L.; Saikaly, P.E. Graphene-Coated Hollow Fiber Membrane as the Cathode in Anaerobic Electrochemical Membrane Bioreactors-Effect of Configuration and Applied Voltage on Performance and Membrane Fouling. Environ. Sci. Technol. 2016, 50, 4439-4447. [CrossRef] [PubMed]

184. Guo, K.; Prévoteau, A.; Rabaey, K. A novel tubular microbial electrolysis cell for high rate hydrogen production. J. Power Sources 2017, 356, 484-490. [CrossRef]

185. Call, D.; Logan, B.E. Hydrogen Production in a Single Chamber Microbial Electrolysis Cell Lacking a Membrane. Environ. Sci. Technol. 2008, 42, 3401-3406. [CrossRef] [PubMed] 